\title{
MEDIA PEMBELAJARAN BERBASIS WEB DENGAN MENGGUNAKAN MICROSOFT EXPRESSION WEB PADA MATA PELAJARAN IPA TERPADU DI SMP NEGERI 2 KONAWE SELATAN
}

Darman, S.Pd., M.Pd

darman@umkendari.ac.id

\begin{abstract}
Abstrak
Tujuan dari Penelitian ini adalah mendesain Aplikasi Media Pembelajaran Berbasis Web Dengan Menggunakan Microsoft Expression Web Pada Mata Pelajaran Ipa Terpadu Di SMP Negeri 2 Konawe Selatan.

Metode yang digunakan dalam penelitian ini adalah metode penelitian pengembangan (Developmen Research), dengan pendekatan deskriptif. Penelitian ini dilaksanakan Di SMP Negeri 2 Konawe Selatan mulai dari tanggal 25 Agustus hingga 2 September 2015. Objek penelitian ini berupa aplikasi media pembelajaran berbasis web dengan menggunakan micrososft expression web pada mata pelajaran Ipa Terpadu. Pengumpulan data dilakukan dengan observasi, dokumentasi dan instrumen. Teknik analisis data dilakukan dengan teknik analisis deskriptif.

Hasil dari penelitian ini adalah Aplikasi media pembelajaran berbasis web dengan menngunakan Microsoft Expression Web yang dikemas dalam Compact Disc (CD). Media pembelajaran berbasis web dinyatakan layak berdasarkan Hasil Uji kelompok kecil/terbatas dengan persentase total sebesar 87,92 dan hasil uji kelompok besar/lebih luas dengan persentasi total sebesar $89,04 \%$, serta hasl validasi oleh ahli media dengan persentase total sebesar 77,27 \%, dan Validasi Ahli materi dengan persentase total sebesar 89,58 \%,. Dari hasil uji di atas dapat disimpulkan bahwa Aplikasi Media Pembelajaran Berbasis Web Dengan Menggunakan Microsoft Expression Web Pada Mata Pelajaran Ipa Terpadu Di SMP Negeri 2 Konawe Selatan yang didesain sangat layak digunakan sebagai media penunjang dalam pembelajaran Ipa Terpadu SMP.
\end{abstract}

Kata Kunci: Media Pembelajaran, Microsoft Expression Web 


\section{PENDAHULUAN}

\section{Latar Belakang}

Perkembangan teknologi informasi yang semakin pesat, kebutuhan akan konsep dan mekanisme belajar mengajar berbasis teknologi informasi (TI) tidak dapat terelakkan lagi sehingga pemanfaatan teknologi sangat perlu dalam metode pembelajaran yang efektif. Teknologi dapat menjadi media pembelajaran yang menarik, berbagai media pembelajaran mulai merambah menggunakan teknologi seperti adanya e-book (buku elektronik) dan e-learning (pembelajaran dengan menggunakan media internet). Pembelajaran berbasis web merupakan sistem pendidikan yang menggunakan aplikasi elektronik untuk mendukung belajar mengajar dengan menggunakan media internet atau media jaringan komputer lainnya. Dengan aplikasi pembelajaran bebasis web memungkinkan siswa tidak harus bertatap muka langsung dengan guru dan penyampaian bahan ajar dan pengembangan ilmu pengetahuan kepada siswa pun dapat dilakukan dengan mudah.

Selama ini proses belajar mengajar antara siswa dan guru di SMP Negeri 2 Konawe Selatan dapat dilakukan jika terjadi pertemuan dan tatap muka langsung antara siswa dan guru di dalam kelas, jika tidak terjadi pertemuan dan tatap muka langsung antara siswa dan guru maka proses belajar mengajar pun tidak dapat dilaksanakan. Selain itu proses penyampaian materi pelajaran sepenuhnya terjadi di dalam kelas sehingga apabila tidak terjadi proses belajar mengajar dapat menyebabkan penyampaian materi pelajaran kepada siswa pun dapat terhambat dan mengakibatkan berkurangnya pemahaman siswa terhadap suatu materi pelajaran tersebut serta materi pelajaran yang diberikan oleh guru di dalam kelas dengan waktu \pm 35 menit mengakibatkan keterbatasan siswa dalam mendapatkan materi pelajaran. Perbedaan daya tangkap siswa dalam setiap mata pelajaran yang disampaikan oleh guru menjadi masalah tersendiri dalam dunia pendidikan khususnya di SMP Negeri 2 Konawe Selatan. Hal itu disebabkan oleh keterbatasan waktu yang dimiliki oleh tenaga pengajar karena harus mengikuti kurikulum yang ada sehingga tidak ada waktu untuk mengulangi materi untuk sebagian siswa yang mungkin belum mengerti. Begitupun juga kepada siswa yang mudah mengerti dan segera mempelajari materi selanjutnya meskipun belum sampai pada waktunya di ajarkan guru di kelas.

Dengan demikian dalam penelitian ini akan dilakukan Desain Aplikasi Media Pembelajaran Berbasis Web dengan menggunakan Microsoft Expression Web. Micrososft Expression Web adalah salah satu aplikasi desain tataletak halaman web. Dengan aplikasi ini memudahkan dalam mendesain tampilan halaman web. Aplikasi media pembelajaran ini dikemas dalam Compact Disk (CD), sehingga dapat digukanan kapanpun dan dimanapun dan dapat digunakan dalam pembelajaran baik berlansung dalam ruang kelas maupun di luar ruang kelas. Salah satu kemudahan dengan aplikasi ini adalah dapat digunakan secara offline maupun online. Dalam aplikasi ini terdiri dari muatan pembelajaran yaitu Judul, tujuan, materi pembelajaran dan evaluasi pembelajaran. Materi ajar disajikan dengan Teks, gambar, animasi dan simulasi, serta dilengkapi dengan soal-soal evaluasi yang bersifat interkatif. Maka Penulis perlu mengadakan penelitian dengan judul "Desain Aplikasi Media Pembelajaran Berbasis Web Dengan Menggunakan Microsoft Expression Web Pada Mata Pelajaran Ipa Terpadu Di SMP Negeri 2 Konawe Selatan".

\section{Rumusan Masalah}

Dari uraian latar belakang dan batasan masalah di atas, maka yang menjadi rumusan masalah dalam penelitian ini adalah Bagaimana mendesain Aplikasi Media Pembelajaran Berbasis Web Dengan Menggunakan Microsoft Expression Web Pada Mata Pelajaran Ipa Terpadu di SMP Negeri 2 Konawe Selatan?

\section{Tujuan Penelitian}

Berdasarkan rumusan masalah di atas, maka tujuan dalam penelitian ini adalah mendesain Aplikasi Media Pembelajaran Berbasis Web Dengan Menggunakan Microsoft Expression Web Pada Mata Pelajaran Ipa Terpadu Di SMP Negeri 2 Konawe Selatan. 


\section{Manfaat Penelitian}

Manfaat yang diharapkan pada penelitian ini adalah :

1. Dapat membantu guru dan siswa dalam pembelajaran Ipa Terpadu.

2. Dapat dijadikan sebagai referensi dalam mengembangkan media pembelajaran di SMP Negeri 2 Konawe Selatan.

3. Dapat dijadikan sebagai media pembelajaran Ipa Terpadu di SMP Negeri 2 Konawe Selatan.

\section{Batasan Masalah}

Aplikasi media pembelajaran berbasis web mempunyai ruang lingkup yang sangat luas, baik itu fitur atapun fasilitas aplikasi itu sendiri. Namun, menyadari keterbatasan waktu dan pengetahuan penulis, maka dalam penelitian ini penulis membatasi masalah :

1. Aplikasi media pembelajaran berbasis web yang akan didesain menggunakan Microsoft expression web.

2. Materi yang akan disampaikan dalam aplikasi ini adalah Mata pelajaran Ipa Terpadu kelas IX semester genap pokok bahasan listrik statis..

\section{Defenisi Istilah}

Aplikasi Media Pembelajaran Berbasis Web adalah suatu aplikasi pembelajaran yang didesain dengan menggunakan aplikasi web site sebagai media yang dapat menyampaikan materi pembejaran.

Microsoft Expression Web adalah salah satu aplikasi desain tata letak halaman web yang menawarkan seperangkat alat untuk desain yang dinamis.

Mata pelajaran Ipa Terpadu merupakan salah satu mata pelajaran di SMP.

\section{TINJAUAN PUSTAKA}

\section{Konsep Media Pembelajaran}

1. Pengertian Media Pembelajaran

Secara etimologi, kata "media" merupakan bentuk jamak dari "medium", yang berasal dan Bahasa Latin "medius" yang berarti tengah. Sedangkan dalam Bahasa Indonesia, kata "medium" dapat diartikan sebagai "antara" atau "sedang" sehingga pengertian media dapat mengarah pada sesuatu yang mengantar atau meneruskan informasi (pesan) antara sumber (pemberi pesan) dan penerima pesan. Media dapat diartikan sebagai suatu bentuk dan saluran yang dapat digunakan dalam suatu proses penyajian informasi (Rusman, 2012).

Istilah media mula-mula dikenal dengan alat peraga, kemudian dikenal dengan istilah audio visual aids (alat bantu pandang/dengar). Selanjutnya disebut instructional materials (materi pembelajaran), dan kini istilah yang lazim digunakan dalam dunia pendidikan nasional adalah instructional media (media pendidikan atau media pembelajaran).

2. Ciri-ciri Media Pembelajaran

Menurut Gerlach dan Ely dalam bukunya Arsyad, Azhar (2006), mengemukakan tiga ciri media yang merupakan petunjuk mengapa media digunakan dan apa saja yang dapat dilakukan oleh media yang mungkin guru tidak mampu (kurang efisien) melakukannya.

a) Ciri fiksatif (Fixative Property)

Ciri ini menggambarkan kemampuan media merekam, menyimpan, melestarikan, dan merekontruksi suatu peristiwa atau objek.

b) Ciri manipulatif (Manipulative Propwerty)
Ciri ini memiliki
makna
bahwa transformasi
suatu
kejadian atau
objek 
dimungkinkan karena media memiliki manipulatif. Kejadian yang memakan waktu sehari-hari dapat disajikan kepada siswa dalam waktu dua atau tiga menit dengan teknik pengambilan gambar.

c) Ciri Distributif (Distributive Property)

Ciri distributif dari media memungkinkan suatu objek atau kejadian ditransportasikan melalui ruang secara bersama kejadian tersebut disajikan kepada jumlah besar siswa dengan stimulus pangalaman yang relatif sama mengenai kejadian itu.

3. Manfaat dan Fungsi Media Pembelajaran

Menurut Sudjana. Nana (2001) manfaat penggunaan media pengajaran, yaitu:

a) Pengajaran lebih menarik perhatian siswa sehingga menumbuhkan motivasi belajar.

b) Bahan pelajaran lebih jelas maknanya sehingga mudah dipahami siswa.

c) Metode mengajar menjadi lebih bervariasi, tidak sekedar komunikasi verbal melalui penuturan kata-kata oleh guru yang membuat siswa cepat bosan.

d) Siswa lebih banyak melakukan kegiatan belajar tidak hanya mendengarkan uraian guru, tetapi aktif mengamati, melakukan, mendemonstrasikan, dan lain-lain.

Fungsi media pengajaran sebagai sumber belajar, Sudjana. Nana (2001), merumuskan fungsi media sebagai berikut:

1. Penggunaan media dalam proses belajar mengajar bukan merupakan fungsi tambahan, tetapi mempunyai fungsi sendiri sebagai alat bantu untuk mewujudkan situasi belajar mengajar yang efektif.

2. Penggunaan media pengajaran merupakan bagian yang integral dari keseluruhan situasi mengajar.

3. Media pengajaran, penggunaannya dengan tujuan dari sisi pelajaran.

4. Penggunaan media bukan semata-mata alat hiburan, bukan sekedar melengkapi proses belajar supaya lebih menarik perhatian siswa.

5. Penggunaan media dalam pengajaran lebih dituangkan untuk mempercepat proses belajar mengajar dan membantu siswa dalam menangkap perhatian yang diberikan guru.

6. Pengunaan media dalam pengajaran diutamakan untuk mempertinggi mutu belajar mengajar.

4. Kriteria Pemilihan Media dalam Pembelajaran

Dalam memilih media kita juga harus mengacu pada kriteria media yang baik. Antara lain, media harus sesuai dengan tujuan pembelajaran, media harus mampu menarik siswa, media dapat memperjelas materi yang abstrak, dan menjalankan fugsinya dalam penyampaian pesan agar proses komunikasi berjalan dengan baik

Sadiman, Arief. S dkk (2006) menyebutkan beberapa hal yang perlu dipertimbangkan dalam pemilihan media yang akan digunakan dalam pembelajaran, antara lain sebagai berikut:

a) Tujuan instruksional yang ingin dicapai

b) Karakteristik dari siswa sebagai sasaran dari penggunaan media

c) Jenis rangsangan belajar yang diharapkan (audio, visual, gerak, dan lainnya)

d) Latar atau keadaan lingkungan di sekitar sekolah

e) Luasnya jangkauan yang diharapkan dapat terpenuhi

Dick dan Carey (Sadiman, Arief. S dkk (2006)) menyebutkan bahwa beberapa

hal yang harus diperhatikan dalam pemilihan media antara lain sebagai berikut:

a) Ketersediaan sumber di lingkungan sekitar sekolah

b) Dana, tenaga, serta fasilitas untuk membuat media tersebut

c) Keluwesan, kepraktisan, dan ketahanan dari media yang akan digunakan

d) Efektivitas biaya yang digunakan dalam pembuatan atau membeli media dalam jangka waktu yang lama.

Dalam merancang media pengajaran perlu memperhatikan beberapa patokan guna mempertinggi daya tarik serta motivasi belajar siswa, antara lain:

a) Kesederhanaan, dalam tata letak (lay out) media pengajaran tampak pada 
gambar yang cukup besar dan jelas rincian pokoknya sehingga terlihat jelas perbedaan antara latar depan dan latar belakang unsur pokok yang ditonjolkan.

b) Keterpaduan, ada hubungan erat di antara berbagai unsur visual sehingga keseluruhannya berfungsi padu.

c) Penekanan, memegang peranan penting dalam media pengajaran walaupun penyajian bersifat tunggal, memiliki keterpaduan, seringkali memerlukan penekanan hanya pada satu unsur yang justru memerlukan titik perhatian siswa.

d) Keseimbangan, mencakup dua macam yaitu keseimbangan formal atau simetris dan keseimbangan informal atau asimetris.

e) Garis berfungsi dalam sebagai unsur visual adalah sebagai penuntun bagi para pengamat (siswa), dalam mempelajari rangkaian konsep, gagasan, makna atau isi pelajaran yang tersirat di dalam media gambar yang dipertunjukkan.

f) Bentuk, bentuk sebagai unsur visual diperlukan dalam sebuah pameran. Tekstur, adalah unsur visual yang memungkinkan timbul suatu kesan kasar atau halusnya permukaan. Tekstur juga dapat digunakan seperti warna dalam hal penekanan, aksentuasi atau pemisahan, serta dapat menambah kesan keterpaduan.

g) Ruang, merupakan unsur gambar yang penting dalam merancang media pengajaran. Hanya dengan pemanfaatan ruang secara hati-hati berbagai unsur visual dari sebuah rancangan media gambar akan menjadi efektif.

h) Warna, merupakan penambahan yang penting untuk sebagian besar media visual, tetapi pemakaiannnya harus hemat dan hati- hati bila menghendaki hasil yang terbaik (Sudjana,Nana. 2001).

\section{Konsep Media Pembelajaran Berbasis Web}

Seiring perkembangan zaman, pemanfaatan internet untuk berbagai kepentingan di Indonesia terus berkembang. Perkembangan teknologi informasi dapat meningkatkan kinerja dan memungkinkan berbagai kegiatan dilaksanakan dengan cepat, tepat, dan akurat, sehingga pada akhirnya dapat meningkatkan produktivitas. Perkembangan teknologi informasi sekarang ini memunculkan berbagai jenis kegiatan berbasis pada teknologi ini, termasuk dalam bidang pendidikan. Teknologi informasi dan komunikasi yang terus berkembang cenderung akan mempengaruhi segenap kehidupan sosial, ekonomi, politik, budaya, serta pendidikan dan pelatihan. Perkembangan teknologi informasi tersebut akan menyebabkan bergesernya sistem pendidikan dan pelatihan dari berorientasi guru ke sistem yang berorientasi siswa dan semakin banyaknya pilihan sumber belajar.

Dengan perkembangan teknologi informasi yang begitu pesat, maka saat ini sudah dimungkinkan dan banyak diterapkan proses belajar jarak jauh dengan menggunakan internet untuk menghubungkan siswa dan guru, melihat jadwal pelajaran, mengirimkan berkas tugas perpelajaranan, melihat nilai, konsultasi, dan bahkan melakukan diskusi. Suatu pendidikan jarak jauh berbasis web antara lain harus memiliki unsur sebagai berikut:

1. Pusat kegiatan siswa, dimana siswa dapat menambah kemampuan, membaca materi pelajaran, mencari informasi dan lainnya.

2. Interaksi dalam group, berupa diskusi sesama siswa dan guru dapat terlibat di dalamnya.

3. Sistem administrasi siswa, dimana siswa dapat melihat status, maupun prestasi mereka.

4. Pendalaman materi dan ujian, yakni materi soal pengayaan bagi siswa yang memerlukan, sesuai dengan kemempuannya.

5. Perpustakaan digital, yakni berisi berbagai informasi kepustakaan baik berupa data base maupun infomasi perpustakaan online yang dapat diakses.

Web merupakan salah satu teknologi internet yang telah berkembang sejak lama dan paling umum dipakai dalam pelaksanaan pendidikan dan latihan jarak jauh. Website merupakan kumpulan dari halaman-halaman web, gambar-gambar, video, atau bahan digital lain yang disimpan dalam web server dan dapat diakses melalui internet.

Secara umum sistem aplikasi di internet terbagi menjadi dua jenis, yaitu synchronous system dan asynchronous system. Synchronous system merupakan aplikasi yang berjalan secara waktu nyata dimana seluruh pemakai dapat berkomunikasi pada waktu yang sama, 
contohnya: chatting, dan video conference. Sedangkan asynchronous system adalah aplikasi yang tidak tergantung pada waktu tertentu, dimana seluruh pemakai dapat mengakses ke sistem dan melakukan komunikasi antar mereka disesuaikan dengan waktunya masing-masing, contohnya: millis dan e-mail. Web pada dasarnya adalah kumpulan informasi yang tersedia di komputer yang bisa diakses karena adanya jaringan yang tersedia di komputer tersebut. Oleh karena itu pembelajaran berbasis web bisa dilaksanakan karena adanya jaringan internet, dan sering disebut dengan nama on-line course.

\section{Pembelajaran Berbasis Web}

Pembelajaran berbasis web merupakan suatu kegiatan pembelajaran yang menanfaatkan media situs (website) yang bisa diakses melalui jaringan internet. Pembelajaran berbasis web merupakan salah satu jenis penerapan dari pembelajarn elektronik. Internet merupakan jaringan yang terdiri atas ribuan bahkan jutaan komputer, termasuk di dalamnya jaringan lokal, yang terhubungkan melalui saluran (satelit, telepon, kabel) dan jangkauanya mencakup seluruh dunia. Internet memiliki banyak fasilitas yang dapat digunakan dalam berbagai bidang, termasuk dalam kegiatan pendidikan. Fasilitas tersebut antara lain: $e-$ mail, Telnet, Internet Relay Chat, Newsgroup, Mailing List (Milis), File Transfer Protocol (FTP), atau World Wide Web (WWW).

Dalam salah satu publikasinya di situs about-elearning.com (dalam rusman, 2012). Himpunan masyarakat Amerika untuk kegiatan pelatihan dan pengembangan (ASTD) mengemukakan defenisi e-learning merupakan proses dan kegiatan peneraroompan pembelajaran berbasis web (web-based learning), pembelajaran berbasirkan ms komputer (computer based learning), kelas virtual (Virtual class room) dan/atau kelas digital (digital classroom). Materi-materi dalam kegiatan pembelajaran elektronik tersebut kebanyakan dihantarkan melalui media internet, intranet, tape video atau audio, penyiaran melalui satelit, televisi interaktif serta $C D$-ROM. Defenisi ini juga menyatakan bahwa defenisi dari e-learning itu bisa bervariasi tergantung dari penyelenggara kegiatan e-learning tersebut dan bagaimana cara penggunaannya, termasuk apa juga tujuan penggunaannya. Salah satu contoh adalah learnframe.com yang menyediakan layanan perangkat lunak e-learning, atau aplikasi content management system (CMS) e-learning Moodle yang banyak digunakan oleh institusi pendidikan konvesional dalam kegiatan blanded learning-nya.

Pembelajaran berbasis web tidaklah sama dengan pembelajaran konvesional. Pembelajaran berbasis web memiliki karakteristik-karakteristik sebagai berikut :

a. Interaktivity (Interaktivitas) : Tersedianya jalur komunikasi yang lebih banyak, baik secara lansung (synchronous), seperti chatting atau messenger atau tidak lansung (asynchronous), seperti maling list, forum dan buku tamu.

b. Independency (Kemandirian) : Fleksibilitas dalam aspek penyediaan waktu, tempat, pengajar, dan bahan ajar.

c. Accessibility (aksesibilitas) : Sumber-sumber belajar lebih mudah diakses melalui pendistribusian dijaringan internet dengan akses yang lebih luas daripada pendistribusian sumber belajar pada pembelajaran konvesional.

d. Enrichmen (Pengayaan) : Kegiatan pembelajaran, persentasi materi ajar dan materi pelatihan sebagai pengayaan, memungkinkan penggunaan perangkat teknologi informasi seperti video streaming, simulasi dan animasi

\section{Fungsi dan Manfaat Pembelajaran Berbasis Web}

Kruse (dalam Rusman, 2012) mengemukakan bahwa pembelajaran berbasis web seringkali memiliki manfaat yang banyak bagi peserta didiknya. Bila dirancang dengan baik dan benar, maka pembelajaran berbasis web bisa menjadi pembelajaran yang menyenagkan, memiliki unsur interaktivitas yang tinggi, menyebabkan peserta didik mengingat lebih banyak materi pelajaran, serta mengurangi biaya-biaya operasional yang biasanya dikeluarkan oleh peserta didik untuk mengikuti pembelajaran.

\section{Kelebihan dan Kekurangan Pembelajaran Berbasis Web}


Sebagai media pada umumnya, pembelajaran berbasis web pun memiliki kelebihan dan kekurangan.

a. Kelebihan

Menurut Rusman (2012) Kelebihan media pembelajaran berbasis web adalah :

1) Memungkinkan setiap orang dimanapun, kapan pun untuk mempelajara apapun.

2) Pelajar dapat belajar sesuai dengan karakteritik dan langkahnya dirinya sendiri karena pembelajaran berbasis web membuat pembelajaran bersifat indifidual.

3) Kemampuan untuk membuat tautan (link), sehingga pembelajar dapat mengakses informasi dari berbagai sumber baik didalam maupun luar lingkungan belajar.

4) Sangat potensial sebagai sumber belajar bagi pembelajar yang tidak memiliki cukup waktu untuk belajar.

5) Dapat mendorong pebelajar untuk lebiha aktif dan mandiri didalam belajar.

6) Menyediakan sumber belajar tambahan yang dapat digunakan untuk meperkaya materi pelajaran.

7) Menyediakan mesin pencari yang dapat digunakan untuk mencari informasi yang merekaa butuhkan.

8) Isi dan materi pembelajaran dapat di -update dengan mudah

b. Kekurangan

Kekurangan media pembelajaran berbasis web menurut Rusman (2012) adalah sebagai berikut :

1) Keberhasilan pembelajaran berbasis web bergantung pada kemandirian dan motivasi pembelajar.

2) Akses untuk mengikuti kegiatan pembelajaran dengan menggunakan web seringkali menjadi masalah bagi pembelajar.

3) Pembelajar dapat cepat merasa bosan dan jenuh jika mereka tidak dapat mengakses informasi, dikarenakan tidak terdapatnya peralatan yang memadai dan bandwith yang cukup.

4) Dibutuhkan panduan bagi pembelajar untuk mencari informasi yang relevan, karena informasi yang ada didalam web sangat beragam.

5) Dengan menggunakan pembelajaran berbasis web, pembelajar terkadang merasa terisolasi, terutama jika terdapat keterbatasan dalam fasilitas komunikasi

\section{Microsoft Expression Web}

Microsoft Expression Web merupakan aplikasi desain tata letak halaman web menggantikan FrontPage yang menawarkan seperangkat alat untuk desain yang dinamis. (Leeds. Chris, dalam Darman 2014). Salah satu kemudahan dalam Microsoft Expressin Web adalah tersedianya template untuk desain CSS juga form untuk ASP.NET. Selain itu, Expressin Web akan membuka halaman web yang sudah ada atau mengimpor berkas dengan ekstensi dari FrontPage, FTP, HTTP atau WebDAV. Microsoft Expression Web menawarkan dukungan terhadap format eXtensible Markup Language (XML) merupakan merupakan bahasa web turunan dari SGML (Standart Generalized Markup Language) yang ada sebelumnya, Secara sederhana XML adalah suatu bahasa yang digunakan untuk mendeskripsikan dan memanipulasi dokumen secara terstruktur. Secara teknis XML didefinisikan sebagai suatu bahasa meta-markup yang menyediakan format tertentu untuk dokumen-dokumen yang mempunyai data terstruktur, Cascading Style Sheet (CSS) 2.1 merupakan merupakan salah satu bahasa pemrograman web untuk mengendalikan beberapa komponen dalam sebuah web sehingga akan lebih terstruktur dan seragam., ASP.NET 2.0 merupakan merupakan framework yang terdiri dari pustaka script client dan komponen server yang terintegrasi, eXtensible HyperText Markup Language (XHTML) merupakan merupakan gabungan dari html (Hyper Text Markup Language) dan xml (Extensible Markup Language), JavaScript adalah bahasa pemrograman yang khusus untuk halaman web agar halaman web menjadi lebih hidup, dan beberapa teknologi standar situs web untuk diintegrasikan ke dalam situs web, (Cheshire. Jim, dalam Darman, 2014). Hasil desain dengan menggunakan Microsoft Expresion Web dapat dilihat pada gambar 2.1. berikut ini. 


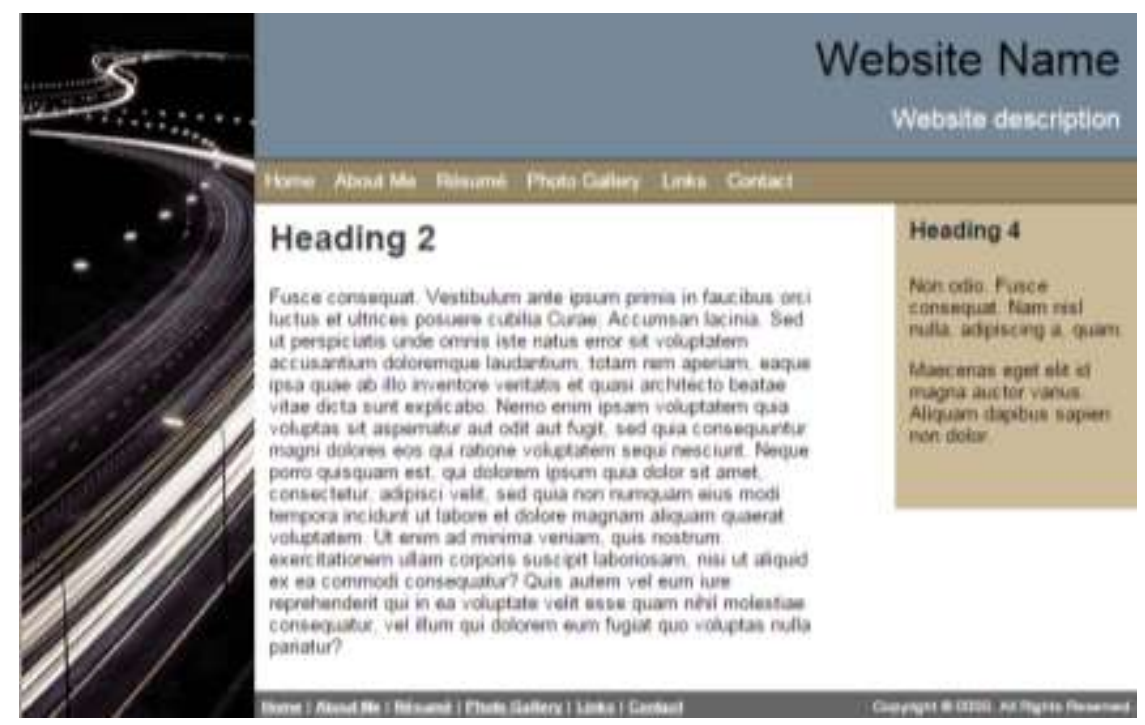

Gambar.2.1. Tampilan Desain dengan Microsoft Expresion Web

Bahasa program pendudkung Microsoft Expression Web adalah sebagai berikut :

1. Cascading Style Sheet(CSS) merupakan merupakan salah satu bahasa pemrograman web untuk mengendalikan beberapa komponen dalam sebuah web sehingga akan lebih terstruktur dan seragam.

2. ASP.NET 2.0 merupakan merupakan framework yang terdiri dari pustaka script client dan komponen server yang terintegrasi.

3. eXtensible HyperText Markup Language (XHTML) merupakan merupakan gabungan dari html (Hyper Text Markup Language) dan xml (Extensible Markup Language).

4. JavaScript adalah bahasa pemrograman yang khusus untuk halaman web agar halaman web menjadi lebih hidup, dan beberapa teknologi standar situs web untuk diintegrasikan ke dalam situs web.

\section{Flowchart}

Flowchart program (biasa disebut flowchart saja), adalah suatu gambar yang menjelaskan urutan Pembacaan data, Pemrosesan data, Pengambilan keputusan terhadap data, Penyajian hasil pemrosesan data. Simbol-Simbol flowchart adalah sebagai berikut :

\begin{tabular}{|c|c|c|}
\hline SIMBOL & NAMA & FUNGSI \\
\hline & TERMINATOR & Permulaan/akhir program \\
\hline & $\begin{array}{l}\text { GARIS ALIR } \\
\text { (FLOW LINE) }\end{array}$ & Arah aliran program \\
\hline & PREPARATION & $\begin{array}{l}\text { Proses inisialisasi/pemberian } \\
\text { harga awal }\end{array}$ \\
\hline & PROCESS & $\begin{array}{l}\text { Proses perhitungan/Proses } \\
\text { pangolahan data }\end{array}$ \\
\hline & INPUT/OUTPUT DATA & $\begin{array}{l}\text { Proses input/output data, } \\
\text { parameter, informasi }\end{array}$ \\
\hline & $\begin{array}{l}\text { PREDETINED } \\
\text { PROCES } \\
\text { (SUB PROGRAM) }\end{array}$ & $\begin{array}{l}\text { Permulaan sub program/proses } \\
\text { menjalankan sub program }\end{array}$ \\
\hline & DECISION & $\begin{array}{l}\text { Parbandingan parnyalaan, } \\
\text { penyolekian data yang } \\
\text { mermberikan pilitan untuk } \\
\text { langkah solanjutnya }\end{array}$ \\
\hline & $\begin{array}{l}\text { ONPAGE } \\
\text { CONNECTOR }\end{array}$ & $\begin{array}{l}\text { Penghubung bagian-bagian } \\
\text { flowchart yang barada pada } \\
\text { oatu halaman }\end{array}$ \\
\hline & $\begin{array}{l}\text { OMPAGE } \\
\text { CONNECTOR }\end{array}$ & $\begin{array}{l}\text { Penghubung bagian bagian } \\
\text { flewrehart yang berada pada } \\
\text { halaman berbeda }\end{array}$ \\
\hline
\end{tabular}




\section{Mata Pelajaran Fisika}

Fisika adalah salah satu ilmu pengetahuan alam dasar yang banyak digunakan sebagai dasar bagi ilmu-ilmu yang lain. Pokok-Pokok bahasan yang akan dibahan dalam aplikasi ini adalah Muatan Listrik,Hukum Coulomb,Medan Listrik,Beda Potensial dan Energi Listrik, Kelistrikan Pada Sel Saraf,Hantaran Listrik,Hewan-Hewan Penghasil Listrik

\section{Standar Kompetensi}

Memahami konsep kelistrikan dan penerapannya dalam kehidupan sehari-hari.

\section{Kompetensi Dasar}

Mendeskripsikan muatan listrik untuk memahami gejala-gejala listrik statis serta kaitannya dalam kehidupan sehari-hari.

\section{Indikator}

- Menjelaskan benda dapat bermuatan listrik bila dilakukan dengan cara tertentu.

- Memberi contoh peristiwa yang menghasilkan benda bermuatan listrik.

- Melakukan percobaan sederhana untuk menunjukkan sifat muatan listrik.

- Menjelaskan secara kualitatif hubungan antara besar gaya listrik, besar muatan listrik dan jarak antara benda bermuatan listrik.

\section{Penelitian yang relevan}

Darman, 2010, dengan judul Desain media pembelajaran berbasis komputer dengan menggunakan Microsoft Expression Web pada Mata Kuliah Pemrograman Web di Universitas Muhammadiyah Kendari. Hasil penelitian ini adalah media pembelajaran berbasis komputer dengan menngunakan Microsoft Expression Web yang dikemas dalam Compact Disc (CD). Media pembelajaran berbasis komputer dinyatakan layak berdasarkan validasi oleh ahli media dan pakar pendidikan dengan persentase total sebesar $84,1 \%$, Ahli materi dengan persentase total sebesar 87,5 \%, Hasil Uji terbatas/kelompok kecil dengan persentase total sebesar $97,08 \%$ dan hasil uji lebih luas/kelompok besar dengan persentasi total sebesar 91,56 \%. Dari hasil uji di atas dapat disimpulkan bahwa media pembelajaran dengan Microsoft Expression Web yang didesain sangat layak digunakan sebagai media penunjang dalam pembelajaran mata kuliah pemrograman web.

\section{METODE PENELITIAN}

\section{Tempat dan Waktu Penelitian}

Penelitian ini akan dilaksakanan di SMP Negeri 2 Konawe Selatan pada bulan Juli sampai bulan September 2015.

\section{Jenis Penelitian}

Metode penelitian ini menggunakan penelitian pengembangan (Development Research). Menurut Sugiono, 2010, Secara umum penelitian pengembangan terdiri dari tiga tahap yaitu : 1) Tahap Pertama adalah Studi Pendahuluan dilakukan dengan pendekatan deskriptif kualitatif, dimulai dengan studi literatur dan Studi lapangan. 2) Tahap Kedua adalah Tahap Pengembangan model dilakukan dengan pendekatan deskriptif dilanjutkan dengan Uji kelompok kecil, setelah ada perbaikan maka dilanjutkan dengan uji coba kelomok besar, sehingga menghasilkan suatu model hipotetik 3) Tahap Ketiga adalah Tahap Evaluasi dengan pendekatan deskriptif kualitatif, Pada tahap ini, Evaluasi dilakukan ditinjau dari aspek media dan aspek materi.

\section{Subjek Penelitian}

Subjek dalam penelitian ini adalah seluruh siswa kelas IX.A SMP Negeri 2 Konawe Selatab dengan rincian : 1) Uji Coba Kelompok Kecil sebanyak 8 orang dan 2) Uji Kelompok besar sebanyak 26 Orang. Dan 5 orang Ahli yang terdiri dari 3 orang ahli media dan 2 orang ahli materi. 


\section{Prosedur Penelitian}

Prosedur penelitian Desain Aplikasi media pembelajaran berbasis web dengan menggunakan Microsoft Expression Web pada mata pelajaran Ipa Terpadu di SMP Negeri 2 Konawe Selatab yang digunakan diadaptasi dari model pengembangan yang dikembangkan oleh sugiono, 2010 yaitu sebagai berikut :

1. Studi Pendahuluan

a) Studi literatur

Pada studi literatur dilakukan mengumpulkan bahan-bahan yang berkaitan dengan penelitian, seperti RPP, Silabus, Materi Ajar, Buku Paket, yang akan dijadikan acuan dalam melakukan desain media pembelajaran berbasis web dengan Microsoft Expression Web.

b) Studi Lapangan

Studi lapangan dilakukan dengan melakukan kunjungan kelas, guna untuk mengetahui media apa yang dibutuhkan dalam pembelajaran Ipa Terpadu. Studi lapangan ini dilakukan di SMP Negeri 2 Konawe Selatab pada kelas IX.

2. Desain Model

a) Memilih materi

Materi dipilih berdasarkan analis kebutuhan, yaitu dengan memilih materi Mata pelajaran Ipa Terpadu Pokok Bahasan Listrik Statis, Dalam media ini materi disajikan dan dilengkapi dengan gambar, video, animasi dan soal evaluasi dalam bentuk pilihan ganda dan esay yang dapat dikerjakan secara interaktif. Artinya siswa dapat mengetahui nilai yang diperoleh dalam mengerjakan soal.

b) Menetapkan Tujuan

Desain media pembelajaran berbasis web pada mata pelajaran Ipa Terpadu Pokok Bahasan Listrik Statis bertujuan untuk mempermudah proses pembelajaran dan memahami materi pembelajaran pelajaran Ipa Terpadu Pokok Bahasan Listrik Statis. Tujuan dari pembelajaran menggunakan media ini adalah agar siswa (i) mampu menguasai materi mata pelajaran Ipa Terpadu Pokok Bahasan Listrik Statis baik secara teori maupun praktik. Di dalam media ini dilengkapi dengan Gambar, Animasi, VideoVideo Percobaan yang relevan dengan materi yang dibahas serta evaluasi dapat dikerjakan secara interaktif..

c) Memilih Layout

Dalam Microsoft Expression Web sudah tersedia Layout atau tampilan yang digunakan. Pemilihan Layout berdasarkan kebutuhan dengan mempertimbangkan komposisi warna terhadap pseserta didik. Maksudnya adalah pemilihan warna tidak boleh terlalu kontras atau tajam sehingga akan membosankan penggunanya.

d) Mengisi Konten

Setelah memilih tampilan (Layout), maka langkah selanjutnya adalah mengisi konten dengan materi-materi yang telah disiapkan. Materi disajikan berdasarkan Silabus dan RPP yang dibuat oleh Guru mata pelajaran Ipa Terpadu.

Langkah selanjutnya dalam desain model. Membuat diagram alir. Diagram alir program merupakan bagan dengan simbol-simbol tertentu yang menggambarkan urutan proses dan hubungna antara proses secara mendetail dalam suatu program. Diagram alir program digunakan untuk menggambarkan tiap-tiap langkah di dalam program komputer secara logika.

e) Uji Coba Kelompok Kecil

Uji coba terbatas melibatkan 8 (Delapan) orang siswa/siswi yang diambil secara random. Uji coba ini bertujuan untuk mengetahui dan mengantisipasi hambatan atau permasalahan awal yang akan muncul ketika produk tersebut digunakan.

f) Uji Coba Kelompok Besar/Lebih Luas

Uji coba Lebih luas/atau kelompok besar melibatkan 26 (dua puluh lima) orang siswa/siswi yang diambil secara random. Uji coba ini bertujuan untuk mengetahui hambatan atau permasalahan yang akan muncul ketika produk tersebut sebelum dilakukan validasi ahli media dan materi. 
3. Analisis Hasil Uji Coba

Data hasil Uji coab baik uji coba kelompok kecil maupun uji coba kelompok besar di analis guna untuk mengetahui kelayakan produk media pembelajaran Ipa Terpadu yang didesain dengan menggunakan Microsoft Expression Web.

4. Revisi I

Revisi dilakukan untuk memperbaiki media yang telah didesain, sebelum dilakukan Validasi

Ahli media dan Ahli Materi.

5. Evaluasi

a) Validasi ahli Media

Validasi ahli media dengan meminta 3 (tiga) orang yang berlatar belakang pendidikan Sarjana Komputer (S.Kom). Validasi ahli media bertujuan untuk mengetahui kelayakan media pembelajaran berbasis web yang didesain dengan menggunakan Microsoft Expression Web dilihat dari aspek media pembelajaran.

b) Validasi Ahli Materi

Validasi ahli materi dengan meminta 2 (dua) orang guru IPA TERPADU SMP Negeri 2 Konawe Selatan. Uji Coba ini bertujuan untuk mengetahui kelayakan media pembelajaran berbasis web yang didesain dengan menggunakan Microsoft Expression Web dari aspek materi.

6. Analisis Hasil Evaluasi

Data hasil validasi ahli media dan ahli materi dianalisis untuk mengetahui kelayakan produk.

7. Revisi II

Revisi digunakan untuk memperbaiki media yang didesain sebelum dilanjutkan dalam Produk Akhir.

Untuk lebih jelasnya, Prosedur Desain Aplikasi Media Pembelajaran berbasis web dengan menggunakan micrososft expression web dapat dilihat pada gambar 3.2.

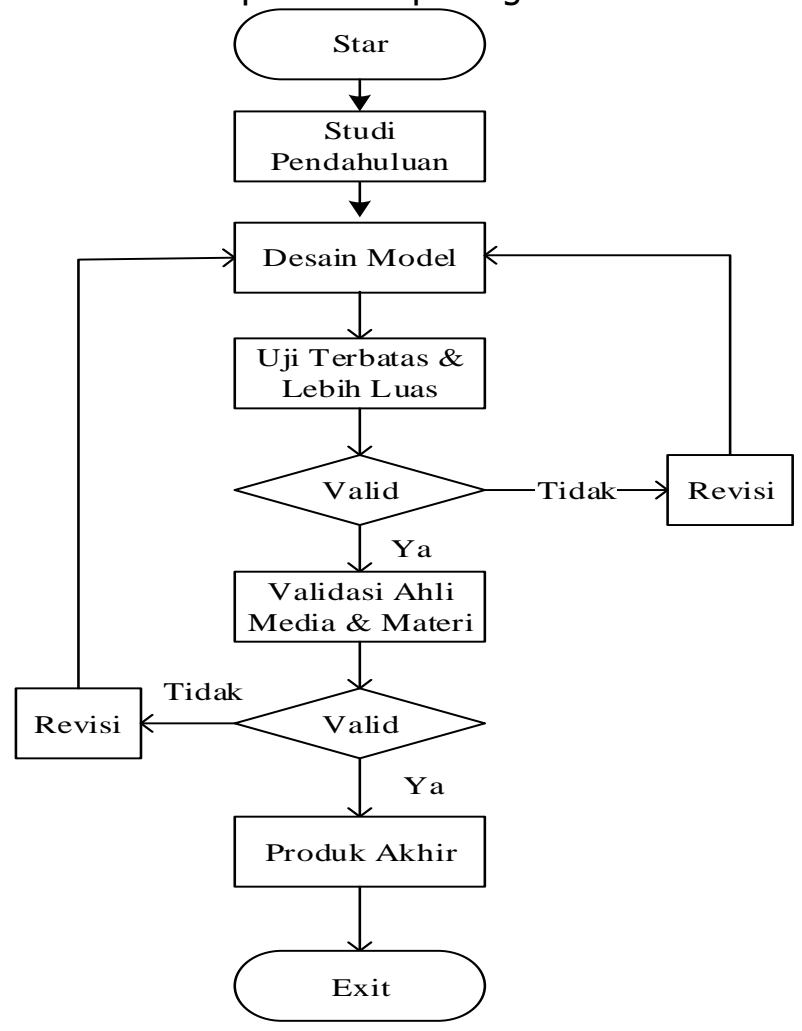

Gambar. 3.6. Flowchart Penelitian Desain Aplikasi Media pembelajaran berbasis web dengan menggunakan Microssoft Expression Web di SMP Negeri 2 Konawe Selatan 


\section{Teknik Pengumpulan Data}

Teknik Pengumpulan data merupakan langkah yang paling strategis dalam penelitian, karena tujuan utama dalam penelitian adalah mendapatkan data. Dalam peneltitian ini teknik pengumpulan data yang digunakan adalah :

1. Observasi. Dalam observasi awal dilakukan untuk mengetahui media apa yang dibutuhkan dalam pembelajaran. Observasi awal dilakuakn dengan melakukan kunjungan kelas pada kelas IX SMP Negeri 2 Konawe Selatab.

2. Dokumentasi. Dokumentasi dilakukan dengan melakukan kajian terhadap literatur-literatus seperti Silabur, RPP, Materi, serta data-data lain yang berkaitan dengan penelitian.

3. Kuisioner. Instrumen kuesioner pada penelitian ini digunakan untuk memperoleh data dari subjek penelitian baik dari subjek uji coba terbatas maupun uji coba lebih luas maupun uji validasi ahli media dan materi sebagai bahan mengevaluasi progam media pembelajaran yang dikembangkan.

a) Instrumen Uji coba kelompok Kecil atau terbatas dan uji coba lebih luas/kelompok besar ini dimaksudkan untuk mengetahui sejauh mana kertertarikan siswa/siswi terhadap materi pembelajaran dan tampilan yang dikemas dalam aplikasi media pembelajaran berbasis web pada mata pelajaran Ipa Terpadu di SMP Negeri 02 Konawe Selatab. Dalam instrumen uji coba ini dinilai dari aspek motivasi terdiri dari 1 pertanyaan dengan nomor item soal nomor 1, dari segi tampilan trerdiri dari 6 pertanyaan dengan item soal nomor 2 sampai nomor 7 dan dari segi materi pembelajaran terdiri dari 3 pertanyaan dengan item nomor soal nomor 8 sampai 10. Berikut kisi-kisi instrumen yang digunakan dalam uji coba kelompok kecil atau terbatas.

Tabel 3.1. Kisi-Kisi Instrumen Uji Coba Kelompok Kecil atau terbatas dan Uji Coba Lebih Luas atau Kelompok Besar

\begin{tabular}{|c|c|c|c|}
\hline $\begin{array}{c}\text { Kategori } \\
\text { Aspek }\end{array}$ & Indikator & $\begin{array}{c}\text { Nomor } \\
\text { Item } \\
\text { Instrumen }\end{array}$ & $\begin{array}{c}\text { Jumlah } \\
\text { Soal }\end{array}$ \\
\hline Motivasi & Ketertarikan penguna & 1 & 1 \\
\hline \multirow{6}{*}{ Tampilan } & Keterbacaan & 2 & \multirow{6}{*}{6} \\
\hline & Mudah digunakan & 3 & \\
\hline & Kualitas Tampilan Penayangan & 4 & \\
\hline & Pengelolan Media & 5 & \\
\hline & Fitur Media & 6 & \\
\hline & Konten Media & 7 & \\
\hline \multirow{3}{*}{$\begin{array}{l}\text { Materi } \\
\text { Pembelajar } \\
\text { an }\end{array}$} & Kejelasan Materi & 8 & \multirow{3}{*}{3} \\
\hline & Kelengkapan Materi & 9 & \\
\hline & Pemahaman Materi & 10 & \\
\hline \multicolumn{3}{|c|}{ Jumlah Soal } & 10 \\
\hline
\end{tabular}

b) Instrumen Validasi ahli media dimaksudkan untuk mengetahui tanggapan terhadap aplikasi media pembelajaran yang didsain dari segi tampilan dan efektifitas serta efisiensi penggunaanya. Dalam validasi ahli media ini dinilai dari aspek komunikasi terdiri dari 5 pertanyaan dengan nomor item soal nomor 1 sampai 5, dari segi Desain Teknis terdiri dari 4 pertanyaan dengan item soal nomor 6 sampai nomor 9 dan dari segi urutan penyajian terdiri dari 2 pertanyaan dengan item nomor soal nomor 10 dan 11 . Berikut ini Kisi-Kisi instrumen ahli media.

Tabel 3.2. Kisi-Kisi Instrumen Validasi Ahli Media

\begin{tabular}{|l|l|c|c|}
\hline Kategori Aspek & \multicolumn{1}{|c|}{ Indikator } & $\begin{array}{c}\text { Nomor Item } \\
\text { Instrumen }\end{array}$ & $\begin{array}{c}\text { Jumlah } \\
\text { Soal }\end{array}$ \\
\hline \multirow{4}{*}{ Komunikasi } & Kemudahan Memahami Program & 1 & \multirow{3}{*}{5} \\
\cline { 2 - 3 } & Logika Berpikir & 2 & \multirow{3}{*}{5} \\
\cline { 2 - 3 } & Interaksi dengan Pengguna & 4 & \\
\cline { 2 - 3 } & Kejelasan Petunjuk Penggunaan & 5 & \\
\cline { 2 - 3 } & Penggunaan Bahasa & 4 & \\
\hline
\end{tabular}




\begin{tabular}{|l|l|c|c|}
\hline Desain Teknis & Format Teks & 6 & \multirow{2}{*}{4} \\
\cline { 1 - 2 } & Penggunaan Warna & 7 & \\
\hline & Kualitas Gambar & 9 & \multirow{2}{*}{2} \\
\hline & Penggunaan Tombol Interaktif & 10 & 11 \\
\hline
\end{tabular}

c) Instrumen validasi ahli materi dimaksudkan untuk mengetahui tanggapan terhadap aplikasi media pembelajaran yang didsain dari segi isi dan tujuan, efektifitas serta efisiensi penggunaanya. Dalam instrumen validasi ahli materi ini dinilai dari aspek isi dan tujuan terdiri dari 4 pertanyaan dengan nomor item soal nomor 1 sampai nomor 4, dari segi efisien trerdiri dari 1 pertanyaan dengan item soal nomor 5 dan dari segi efektifitas terdiri dari 1 pertanyaan dengan item nomor soal nomor 6 . Berikut ini kisi-kisi instrumen aplikasi media pembelajaran berbasis web dengan menggunakan Micrososft Expression Web untuk ahli materi.

Tabel. 3.3. Kisi-Kisi Validasi Ahli Materi

\begin{tabular}{|l|l|c|c|}
\hline \multirow{2}{*}{ Kategori Aspek } & \multicolumn{1}{|c|}{ Indikator } & $\begin{array}{c}\text { Nomor } \\
\text { Item } \\
\text { Instrumen }\end{array}$ & $\begin{array}{c}\text { Jumlah } \\
\text { Soal }\end{array}$ \\
\hline \multirow{3}{*}{ Isi dan Tujuan } & Ketepatan & 1 & \multirow{2}{*}{4} \\
\cline { 2 - 3 } & Keseimbangan & 2 & \\
\cline { 2 - 3 } & Minat Perhatian & 3 & \\
\cline { 2 - 3 } & Kesesuaian & 5 & 1 \\
\hline Efisien & Efisien program & 6 & 6 \\
\hline Efektifitas & Efektifitas program & & 1 \\
\hline \multicolumn{2}{|l|}{ Jumlah Soal } \\
\hline
\end{tabular}

\section{Teknik Analisis Data}

Data yang diperoleh melalui instrumen penilaian pada saat uji coba dianalisis dengan menggunakan statistik deskriptif kualitatif. Analisis ini dimaksudkan untuk menggambarkan karakteristik data pada masing-masing variabel. Dengan cara ini diharapkan akan mempermudah memahami data untuk proses analisis selanjutnya. Hasil analisis data digunakan sebagai dasar untuk merevisi produk media yang dikembangkan. Teknik analisis data yang dilakukan adalah menggunakan teknik analisis deskriptif kualitatif yaitu memaparkan hasil pengembangan produk yang berupa media pembelajaran berbasis komputer, menguji tingkat validasi dan kelayakan produk untuk diimplementasikan pada mata pelajaran Ipa Terpadu. Data yang terkumpul diproses dengan cara dijumlahkan, dibandingkan dengan jumlah yang diharapkan dan diperoleh persentase (Arikunto, 1996), atau dapat ditulis dengan rumus sebagai berikut :

$$
\text { Persentase Kelayakan (\%) }=\frac{\text { Skor yang diobservasi }}{\text { Skor yang diharapkan }} \text { X } 100 \%
$$

Data yang terkumpul dianalisis dengan teknik analisis deskriptif kuantitatif yang diungkapkan dalam distribusi skor dan persentase terhadap kategori skala penilaian yang telah ditentukan. Setelah penyajian dalam bentuk persentase, langkah selanjutnya mendeskriptifkan dan mengambil kesimpulan tentang masing-masing indikator. Kesesuaian aspek dalam pengembangan bahan ajar dan media pembelajaran dapat menggunakan tabel berikut:

Tabel 3.4. Tabel skala persentase

\begin{tabular}{|c|c|}
\hline Persentase Pencapaia & Interprestasi \\
\hline $76-100 \%$ & Sangat Layak \\
\hline $56-75 \%$ & Layak \\
\hline $40-55 \%$ & Tidak Layak \\
\hline $0-39 \%$ & Sangat Tidak Layak \\
\hline
\end{tabular}

Sumber : Arikunto (1996) 
Tabel 3.5 Bobot Penilaian

\begin{tabular}{|c|c|}
\hline Interprestasi & Bobot \\
\hline Sangat Layak & 4 \\
\hline Layak & 3 \\
\hline Tidak Layak & 2 \\
\hline Sangat Tidak Layak & 1 \\
\hline
\end{tabular}

Pada tabel 3.4 di atas disebutkan presentase pencapaian, dan interprestasi. Untuk mengetahui bobot kelayakan digunakan tabel 3.5 diatas sebagai acuan penilaian data yang dihasilkan dari validasi ahli media dan ahli materi dan uji kelompok kecil serta uji coba kelompok besar.

\section{Pembahasan Hasil Penelitian}

1. Hasil Desain

Media pembelajaran berbasis web yang telah didesain dengan menggunakan Microsoft Expression Web adalah sebagai berikut :

a) Halaman Beranda

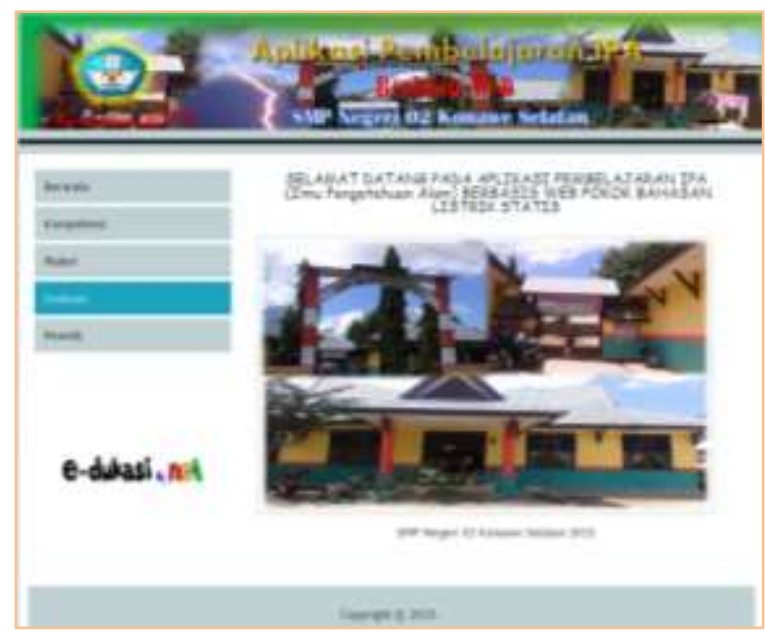

Sumber : Hasil Desain, 2015

Gambar 4.1. Halaman Beranda

b) Halaman Kompetensi

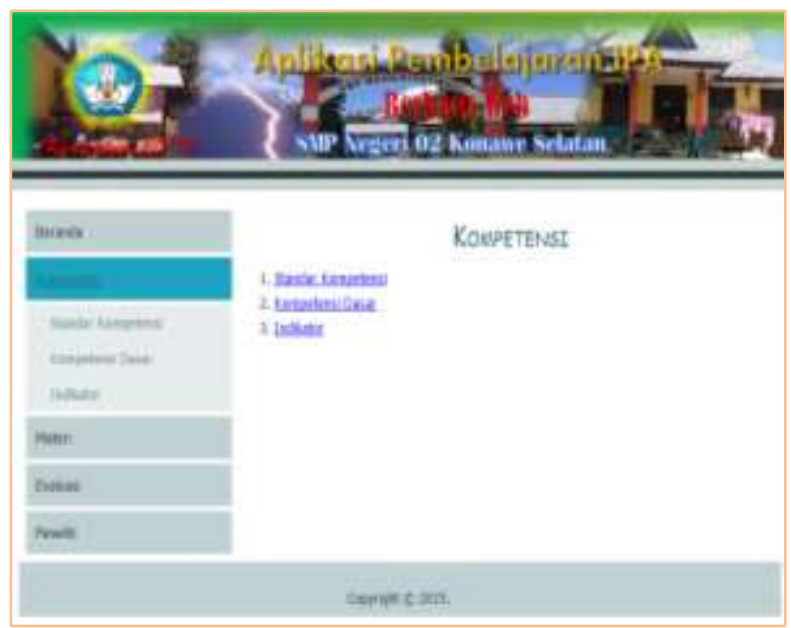

Sumber : Hasil Desain, 2015

Gambar 4.2. Halaman Kompetensi 
c) Halaman Standar Kompetensi

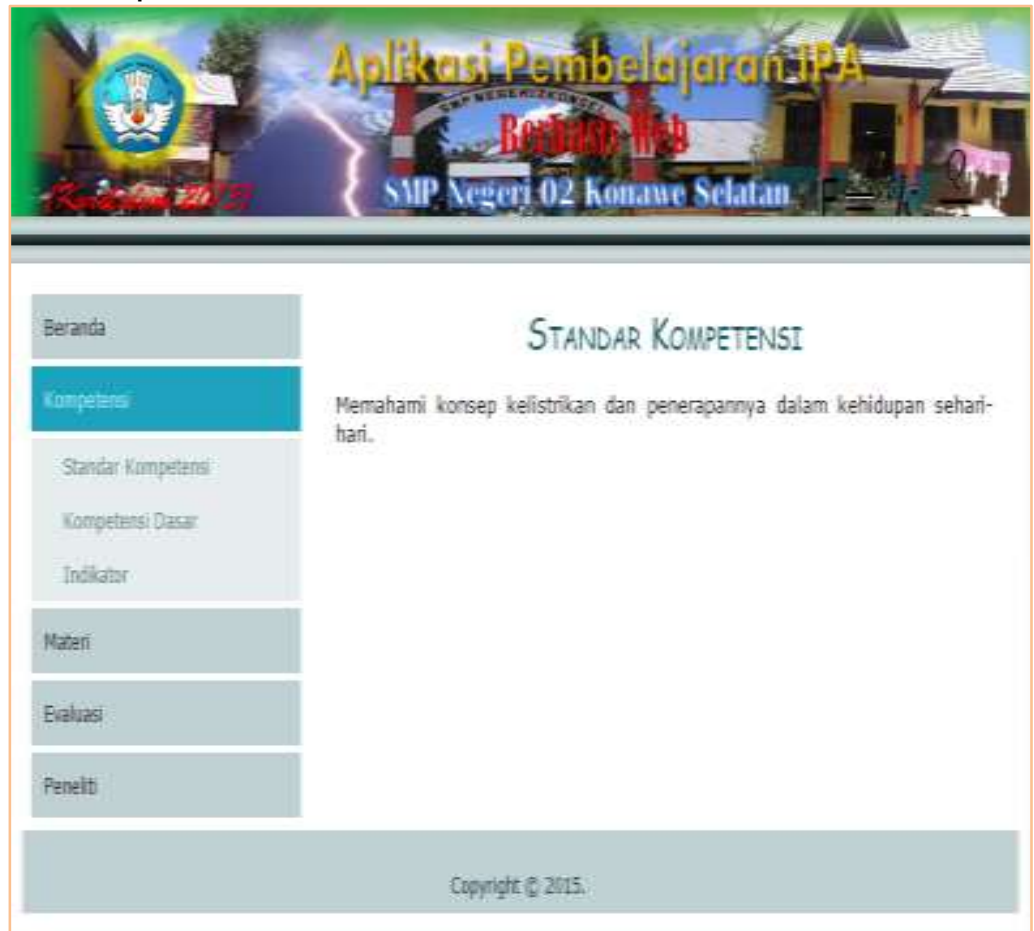

Sumber : Hasil Desain, 2015

Gambar 4.3. Halaman Standar Kompetensi

d) Halaman Kompetensi Dasar

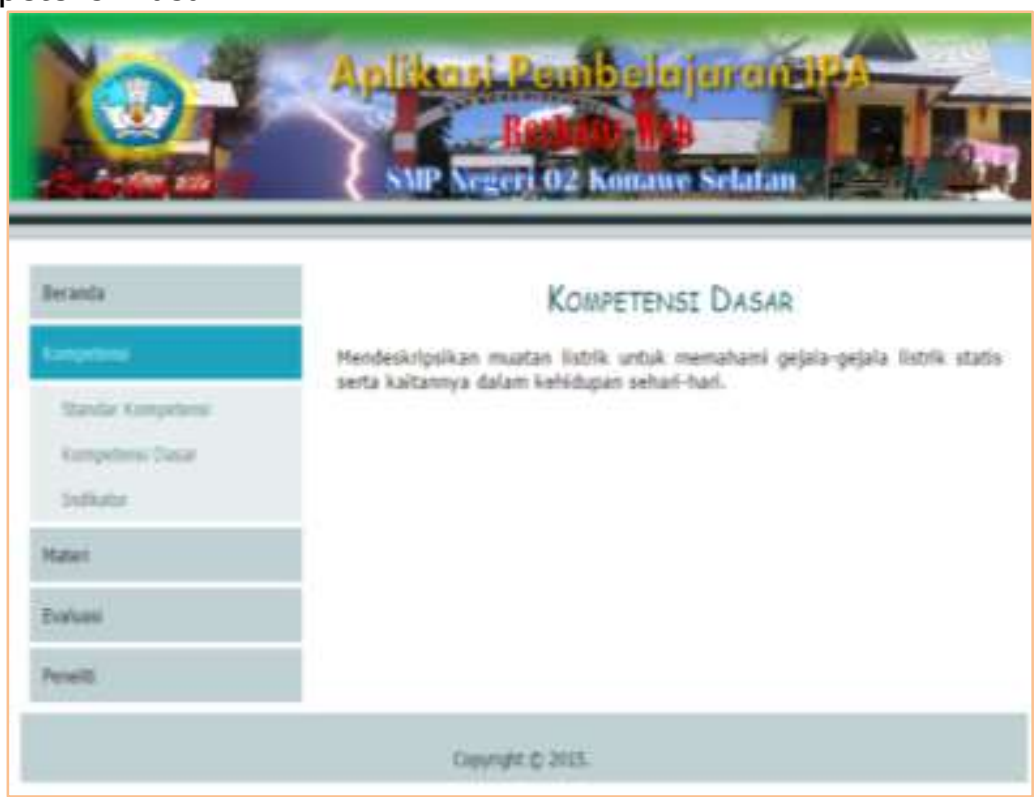

Sumber : Hasil Desain, 2015

Gambar 4.4. Halaman Kompetensi Dasar 
e) Halaman Indikator
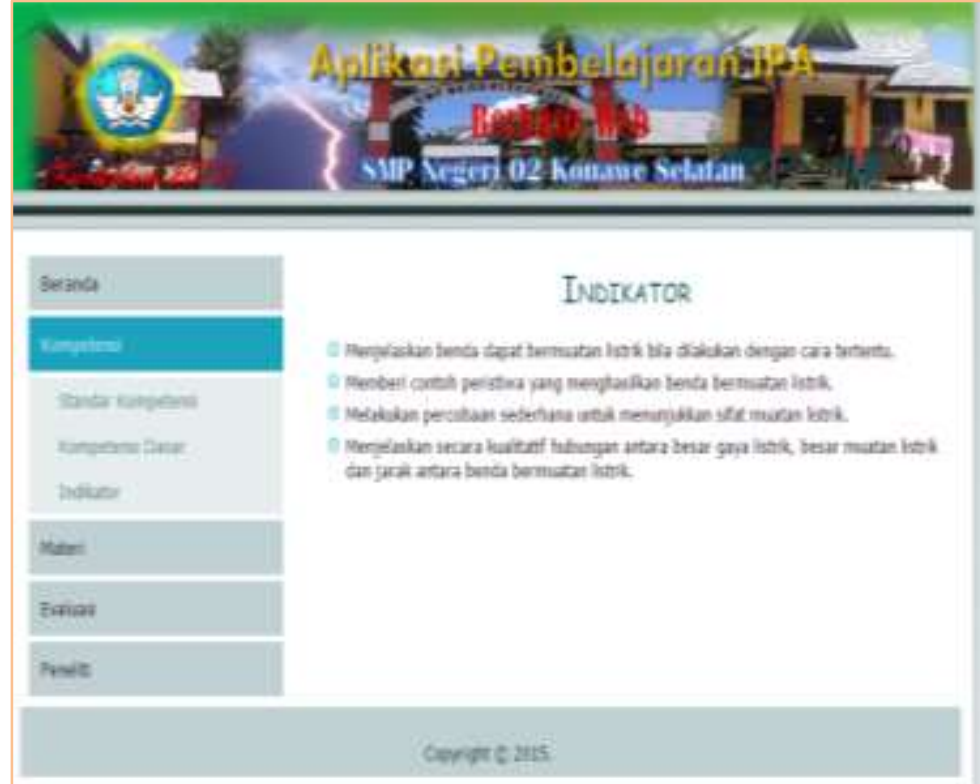

Sumber : Hasil Desain, 2015

Gambar 4.5. Halaman Indikator

f) Halaman Materi

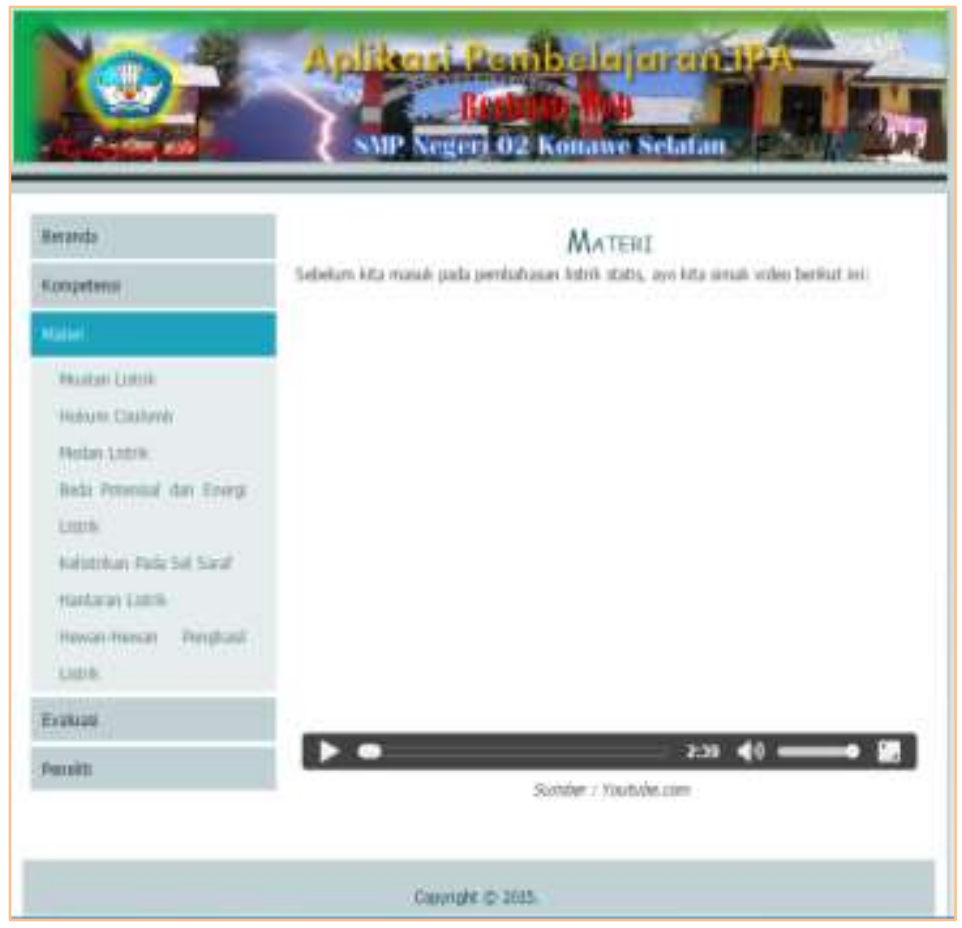

Sumber : Hasil Desain, 2015

Gambar 4.5. Halaman Materi 
g) Halaman Materi Muatan Listrik

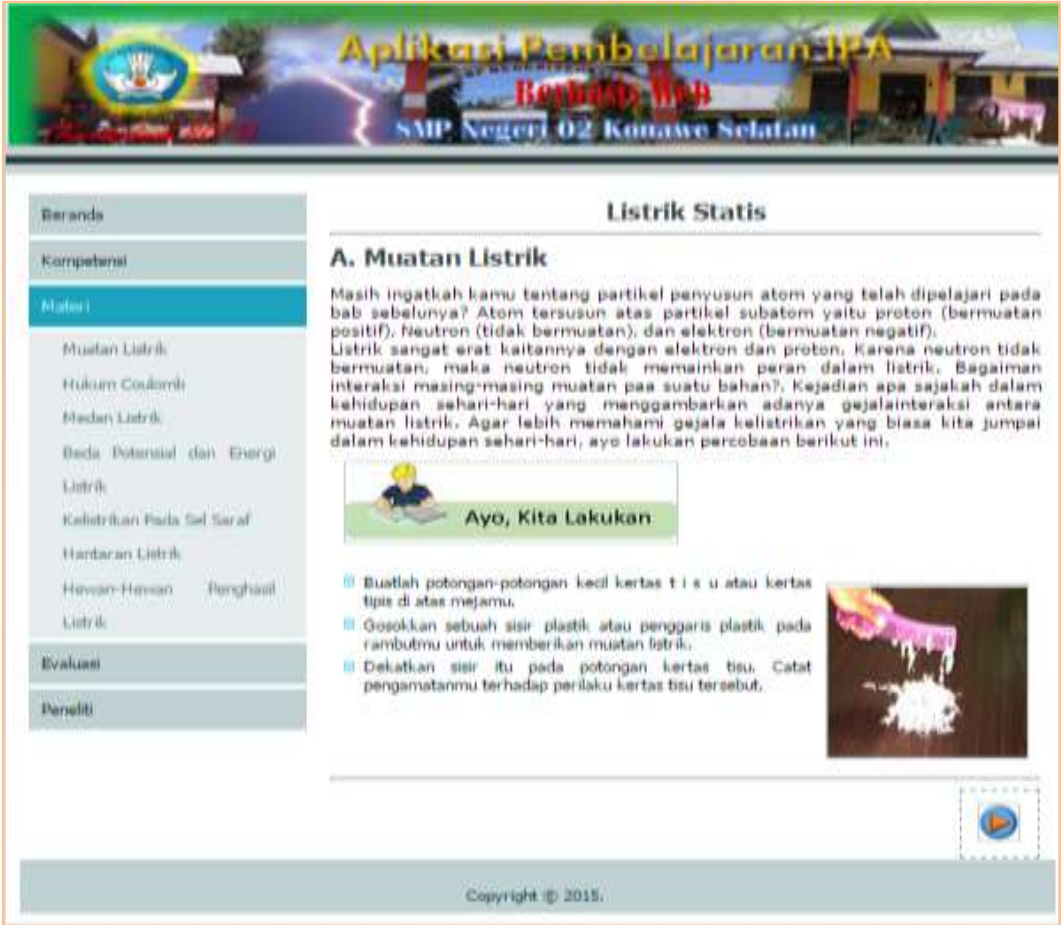

Sumber : Hasil Desain, 2015

Gambar 4.7. Halaman Materi Muatan Listrik

h) Halaman Materi Hukum Coulomb

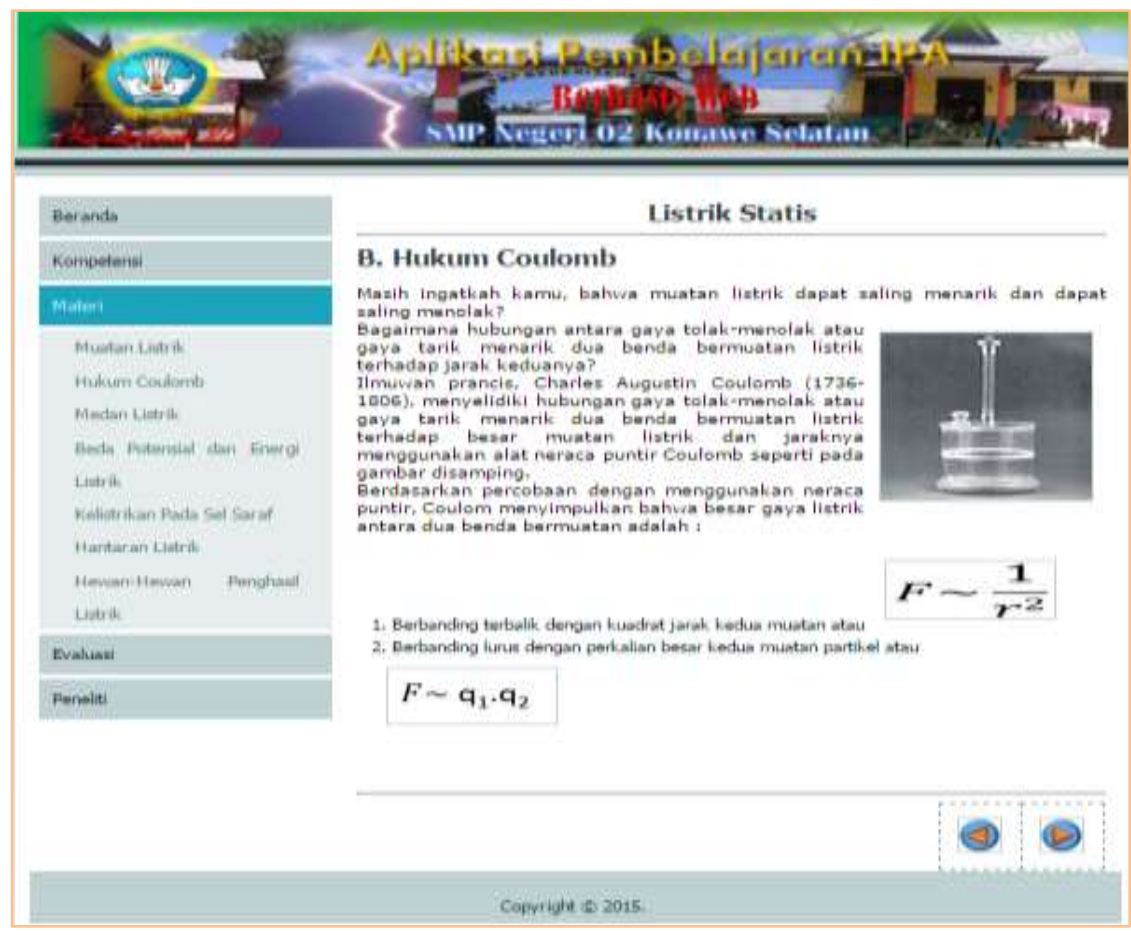

Sumber : Hasil Desain, 2015

Gambar 4.8. Halaman Materi Hukum Coulomb 
i) Halaman Materi Medan Listrik

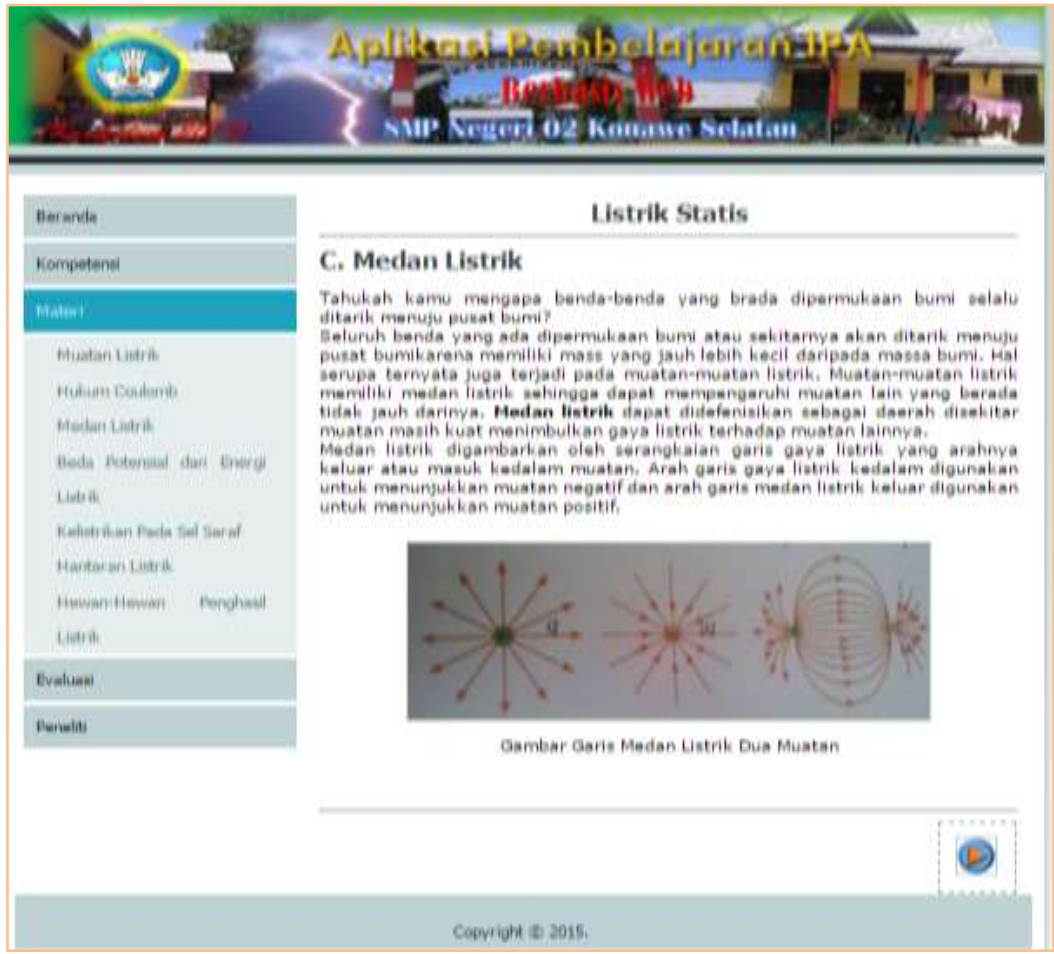

Sumber : Hasil Desain, 2015

Gambar 4.9. Halaman Materi Medan Listrik

j) Halaman Materi Beda Potensial dan Energi Listrik

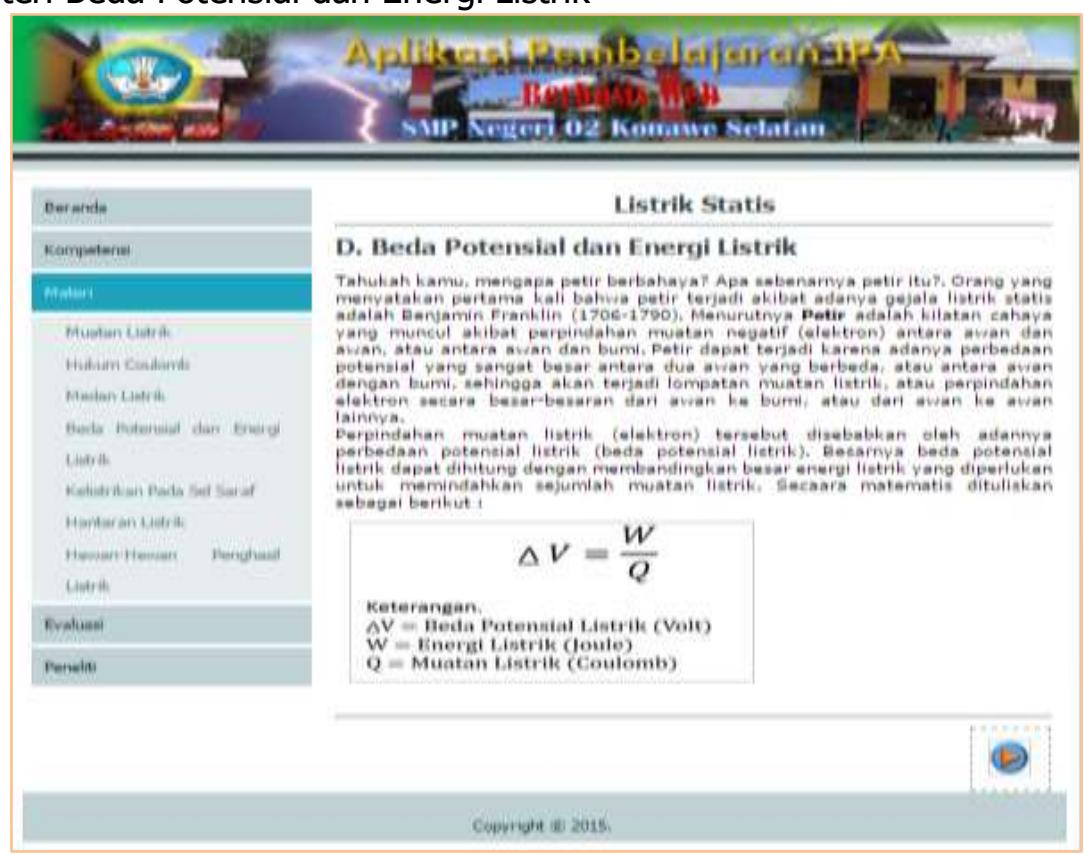

Sumber : Hasil Desain, 2015

Gambar 4.10. Halaman Materi Beda Potensial dan Energi Listrik 
k) Halaman Materi Kelistrikan pada Sel Sarah

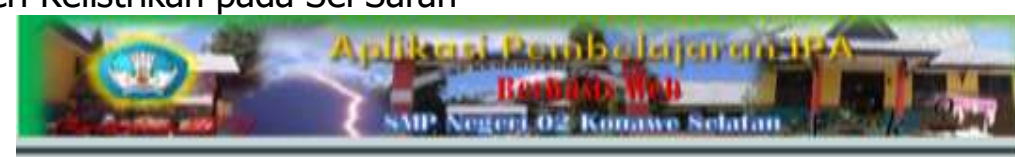

\begin{tabular}{|c|}
\hline Bainends \\
\hline Rorpetertis \\
\hline Mativen \\
\hline Mastan Lavik \\
\hline tedum cesiome \\
\hline Medan Limin \\
\hline Dedu Potemial das Coeve \\
\hline Lutrit \\
\hline Katuedan Prite Sel Farat \\
\hline Meptaian Levik \\
\hline 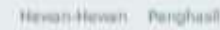 \\
\hline Lenk \\
\hline Evalias: \\
\hline Feneniti \\
\hline
\end{tabular}

Listrik Statis

E. Kelistrikan Pada Sel Saraf

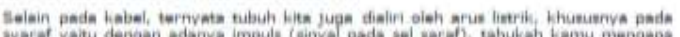

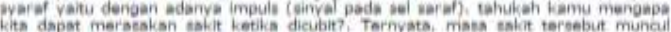

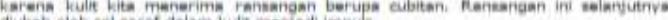

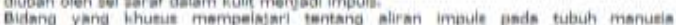

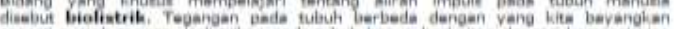

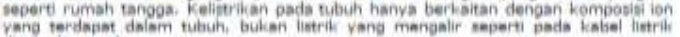

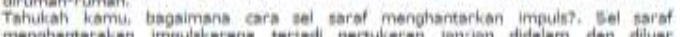

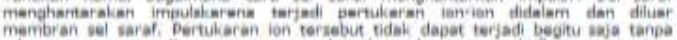

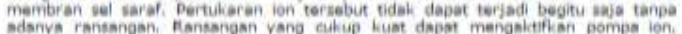

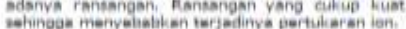

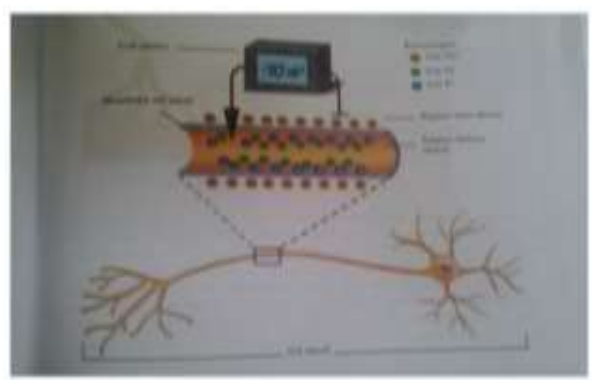

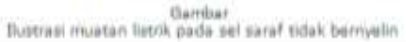

Sumber : Hasil Desain, 2015

Gambar 4.11. Halaman Materi Kelistrikan pada Sel Saraf

I) Halaman Materi Hantaran Listrik
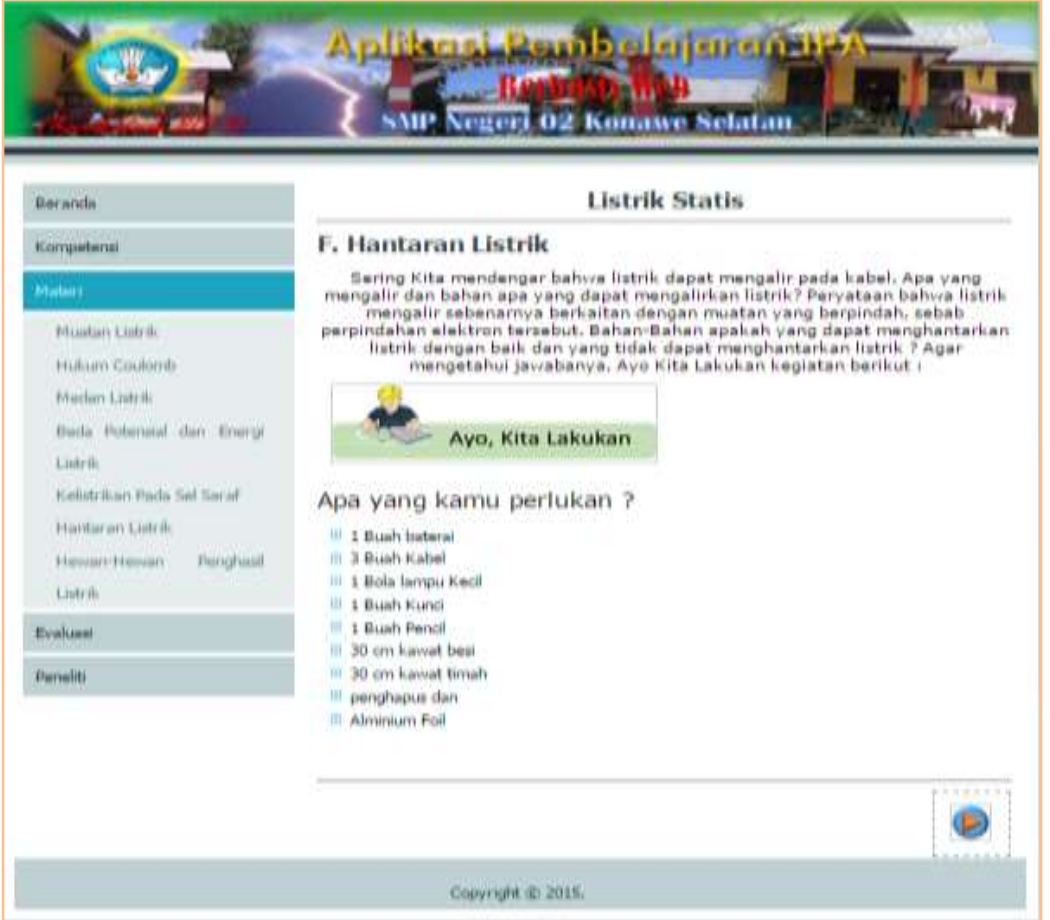

Sumber : Hasil Desain, 2015

Gambar 4.12. Halaman Materi Hantaran Listrik 
m) Halaman Materi Hewan-Hewan Penghasil Listrik

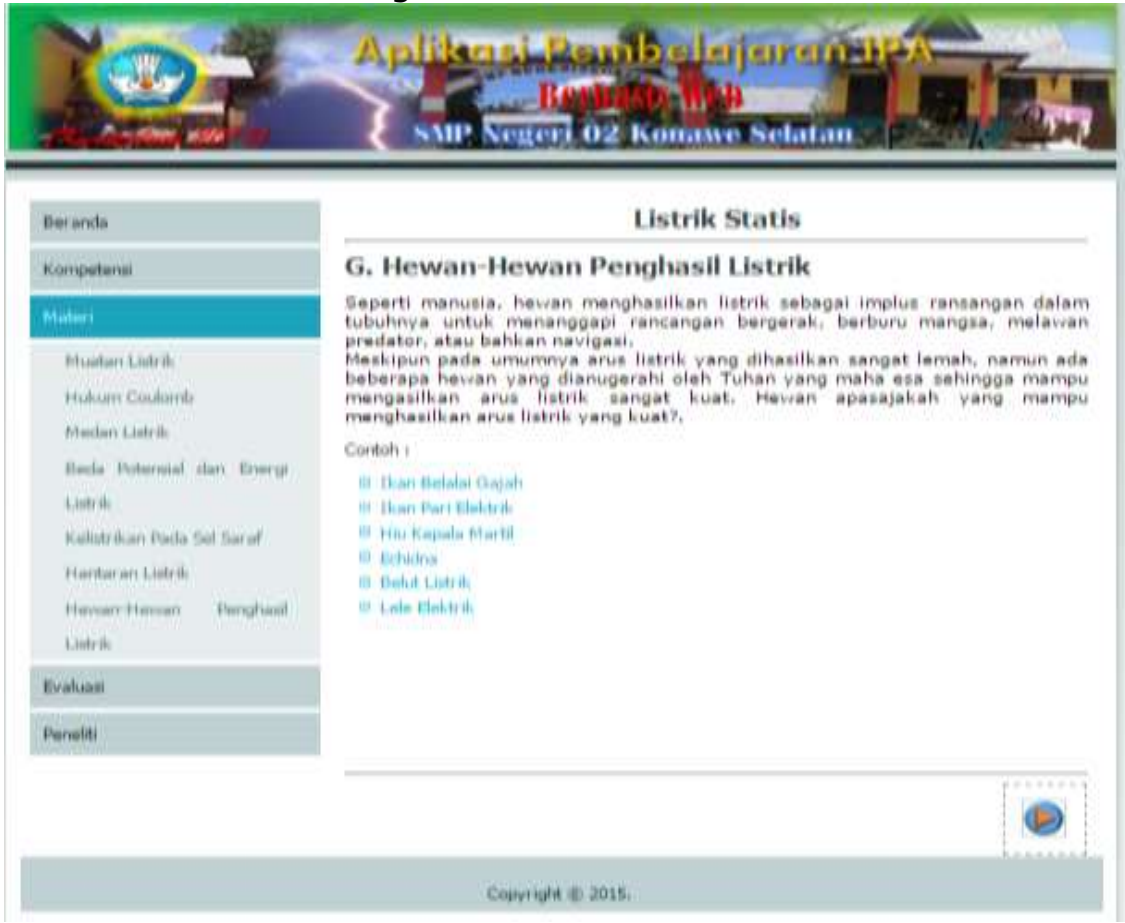

Sumber : Hasil Desain, 2015

Gambar 4.13. Halaman Materi Hewan-Hewan Penghasil Listrik

n) Halaman Evaluasi

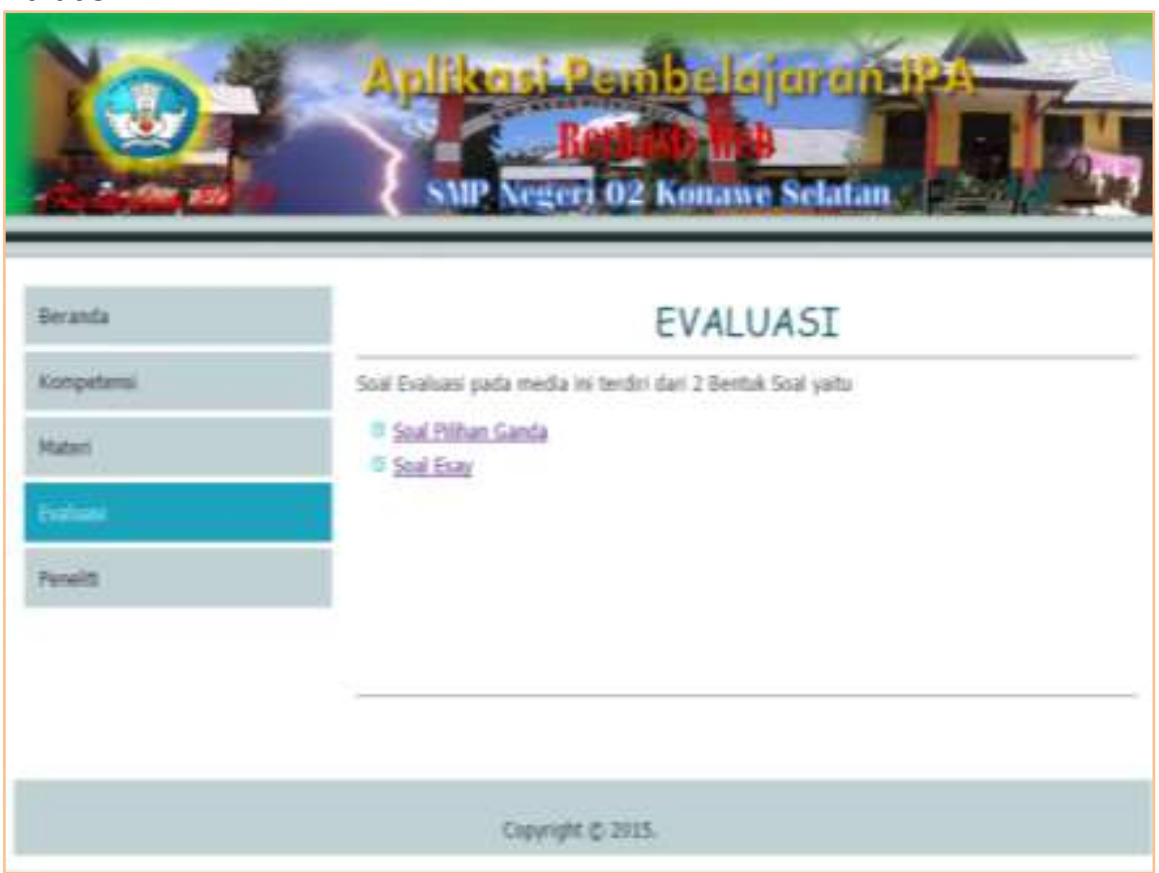

Sumber : Hasil Desain, 2015

Gambar 4.14. Halaman Evaluasi 
o) Halaman Evalusi Pilihan Ganda

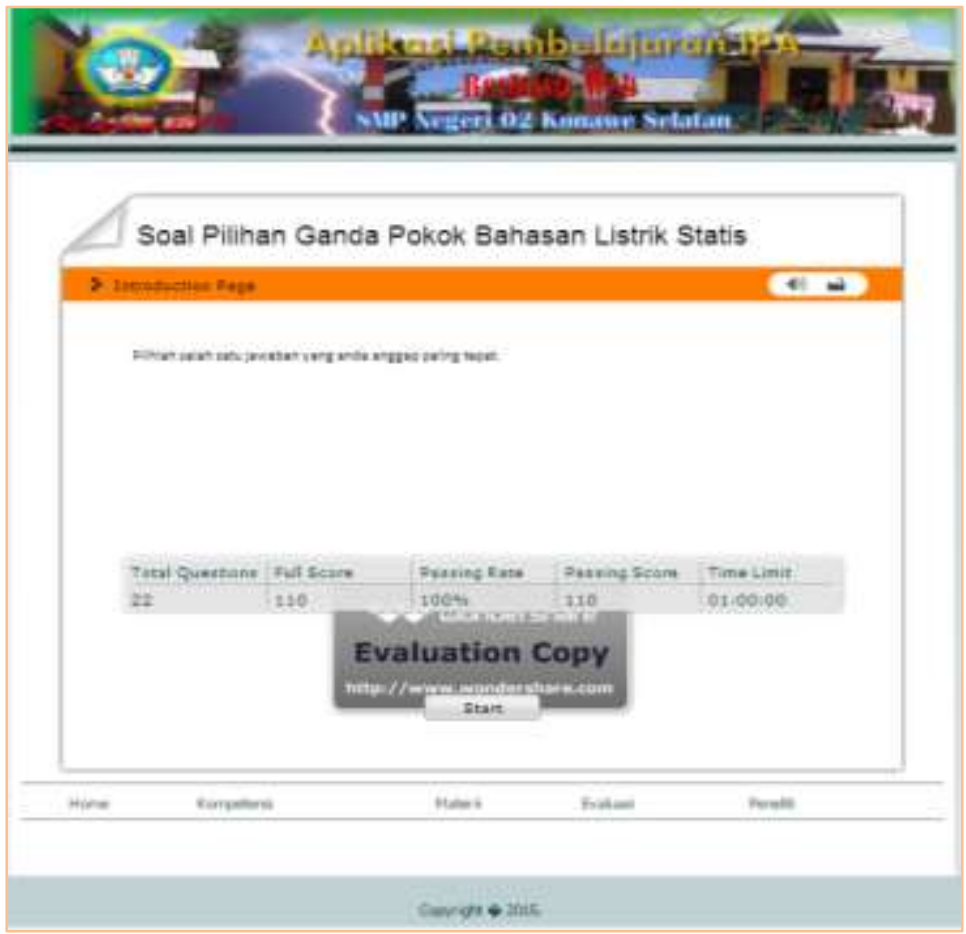

Sumber : Hasil Desain, 2015

Gambar 4.15. Halaman Soal Pilihan Ganda

p) Halaman Evaluasi Esay

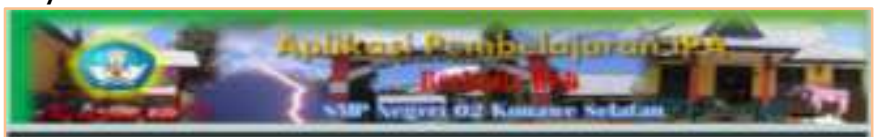

Sumber : Hasil Desain, 2015

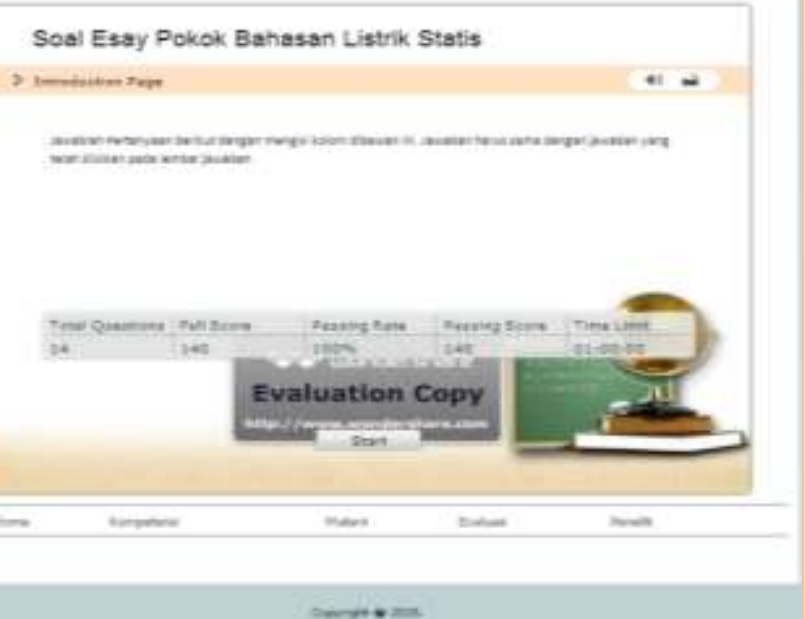

Gambar 4.16. Halaman Soal Esay

\section{Hasil Pengujian Kelayakan}

Aplikasi Media Pembelajaran Berbasis Web Dengan Menggunakan Microsoft Expression Web Pada Mata Pelajaran Ipa Terpadu Di SMP Negeri 2 Konawe Selatan yang telah dibuat kemudian dilakukan uji coba baik uji coba kelompok kecil/terbatas maupun uji 
coba kelompok besar/lebih luas dan validasi baik validasi ahli media maupun validari ahli materi. Berikut ini pembahasan dari masing-masing pengujian kelayakan media :

Pengujian kelayakan Aplikasi Media Pembelajaran Berbasis Web Dengan Menggunakan Microsoft Expression Web Pada Mata Pelajaran Ipa Terpadu Di SMP Negeri 2 Konawe Selatan di lakukan dengan uji coba kelompok kecil atau terbatas dengan melibatkan 6 orang siswa (i) diperoleh hasil sebagai berikut : dari aspek motivasi, yang terdiri dari 1 item pertanyaan yaitu ketertarikan pengguna, memperoleh nilai 21 atau 87,50 \%, Dari aspek tampilan yant terdiri dari 6 pertanyaan yaitu Keterbacaan, Mudah digunakan, Kualitas tampilan penayangan, pengelolaan media, fitur media dan konten media, memperoleh nilai sebesar 126 atau 87,50 \%, dan dari aspek materi terdiri dari 3 pertanyaan yaitu Kejelasan materi, kelengkapan materi dan pemahaman materi memperoleh nilai 64 atau 88,89\%. Dari data di atas, secara keseluruhan hasil uji coba kelompok kecil atau terbatas Aplikasi Media Pembelajaran Berbasis Web Dengan Menggunakan Microsoft Expression Web Pada Mata Pelajaran Ipa Terpadu Di SMP Negeri 2 Konawe Selatan memperoleh nilai sebesar 211 atau sebesar 87,92 \%, sesuai dengan table 3.4. pada bab III di atas sangat layak. Dengan demikian Aplikasi Media Pembelajaran Berbasis Web Dengan Menggunakan Microsoft Expression Web Pada Mata Pelajaran Ipa Terpadu Di SMP Negeri 2 Konawe Selatan diinterprestasikan sangat layak digunakan dalam pembelajaran Ipa Terpadu.

Tabel 4.1. Uji Kelompok Kecil atau Terbatas

\begin{tabular}{|l|l|l|l|l|l|}
\hline No. & \multicolumn{1}{|c|}{ Aspek Penilaian } & $\begin{array}{c}\text { Skor } \\
\text { Observasi }\end{array}$ & $\begin{array}{c}\text { Skor Yang } \\
\text { diharapkan }\end{array}$ & $\begin{array}{c}\text { Kelayakan } \\
(\%)\end{array}$ & \multicolumn{1}{|c|}{ Ket. } \\
\hline 1. & Motivasi & 21 & 24 & 87,50 & Sangat Layak \\
\hline 2. & Tampilan & 126 & 144 & 87,50 & Sangat Layak \\
\hline 3. & Materi Pembelajaran & 64 & 72 & 88,88 & Sangat Layak \\
\hline Jumlah & 211 & 240 & 87,92 & Sangat Layak \\
\hline
\end{tabular}

Sumber : Hasil Olahan, 2015

Apabila digambarkan dalam diagram batang adalah sebagai berikut :

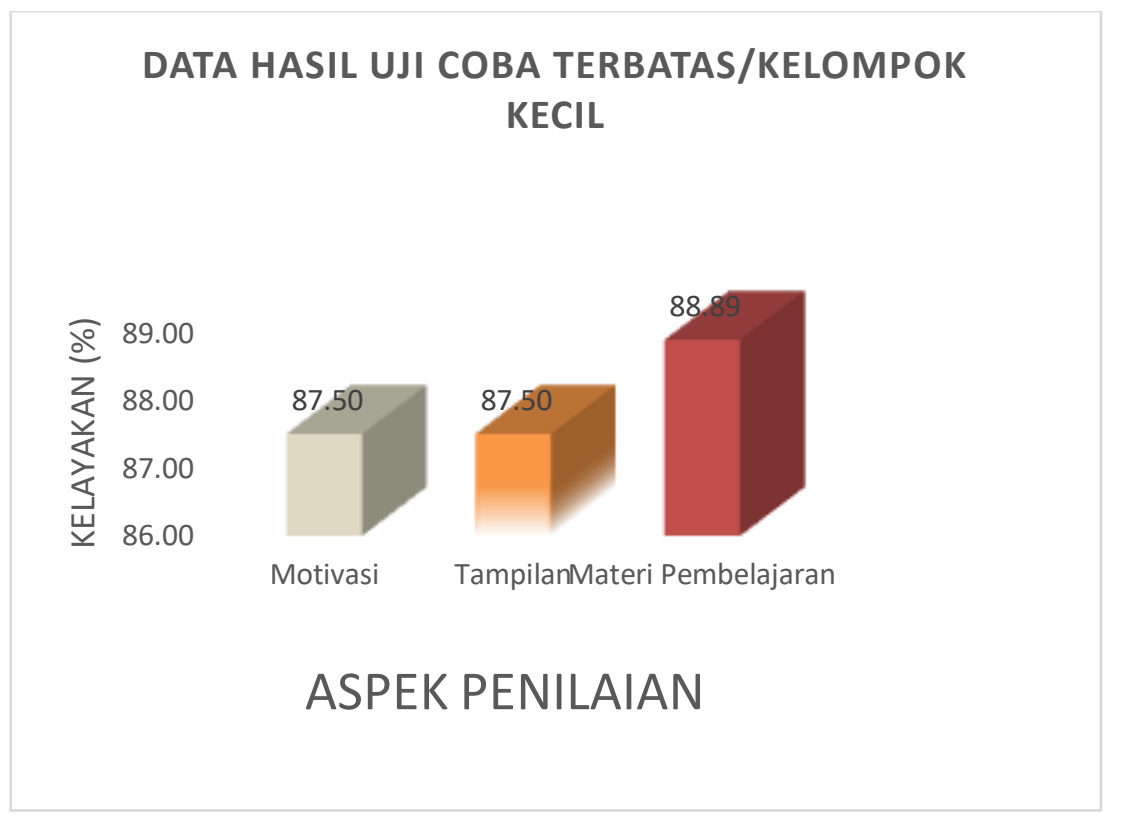

Gambar 4.1. Diagram Batang Uji Kelompok Kecil Oleh Siswa

Hasil uji coba kelompok besar atau lebih luas dengan melibatkan 26 orang siswa (i) diperoleh hasil sebagai berikut : dari aspek motivasi, yang terdiri dari 1 item pertanyaan yaitu ketertarikan pengguna, memperoleh nilai 96 atau 94,23 \%, Dari aspek tampilan yant 
terdiri dari 6 pertanyaan yaitu Keterbacaan, Mudah digunakan, Kualitas tampilan penayangan, pengelolaan media, fitur media dan konten media, memperoleh nilai sebesar 547 atau 87,66 \%, dan dari aspek materi terdiri dari 3 pertanyaan yaitu Kejelasan materi, kelengkapan materi dan pemahaman materi memperoleh nilai 281 atau 90,06 \%. Dari data di atas, secara keseluruhan hasil uji coba kelompok besar atau lebih luas Aplikasi Media Pembelajaran Berbasis Web Dengan Menggunakan Microsoft Expression Web Pada Mata Pelajaran Ipa Terpadu Di SMP Negeri 2 Konawe Selatan memperoleh nilai sebesar 926 atau sebesar 89,04 \%, sesuai dengan table 3.4. pada bab III di atas sangat layak. Dengan demikian Aplikasi Media Pembelajaran Berbasis Web Dengan Menggunakan Microsoft Expression Web Pada Mata Pelajaran Ipa Terpadu Di SMP Negeri 2 Konawe Selatan diinterprestasikan sangat layak digunakan dalam pembelajaran Ipa Terpadu.

Tabel 4.2. Uji Kelompok Besar atau Lebih Luas

\begin{tabular}{|l|l|l|l|l|l|}
\hline No. & \multicolumn{1}{|c|}{$\begin{array}{c}\text { Aspek } \\
\text { Penilaian }\end{array}$} & $\begin{array}{c}\text { Skor } \\
\text { Observasi }\end{array}$ & $\begin{array}{c}\text { Skor Yang } \\
\text { diharapkan }\end{array}$ & $\begin{array}{c}\text { Kelayakan } \\
(\%)\end{array}$ & \multicolumn{1}{|c|}{ Ket. } \\
\hline 1. & Motivasi & 98 & 104 & 94,23 & Sangat Layak \\
\hline 2. & Tampilan & 547 & 624 & 87,66 & Sangat Layak \\
\hline 3. & $\begin{array}{l}\text { Materi } \\
\text { Pembelajaran }\end{array}$ & 281 & 312 & 90,06 & Sangat Layak \\
\hline \multicolumn{2}{|l|}{ Jumlah } & 926 & 1,040 & 89,04 & Sangat Layak \\
\hline
\end{tabular}

Sumber : Hasil Olahan, 2015

Apabila digambarkan dalam diagram batang adalah sebagai berikut:

\section{Data Uji Coba Kelompok Besar/Lebih Luas}

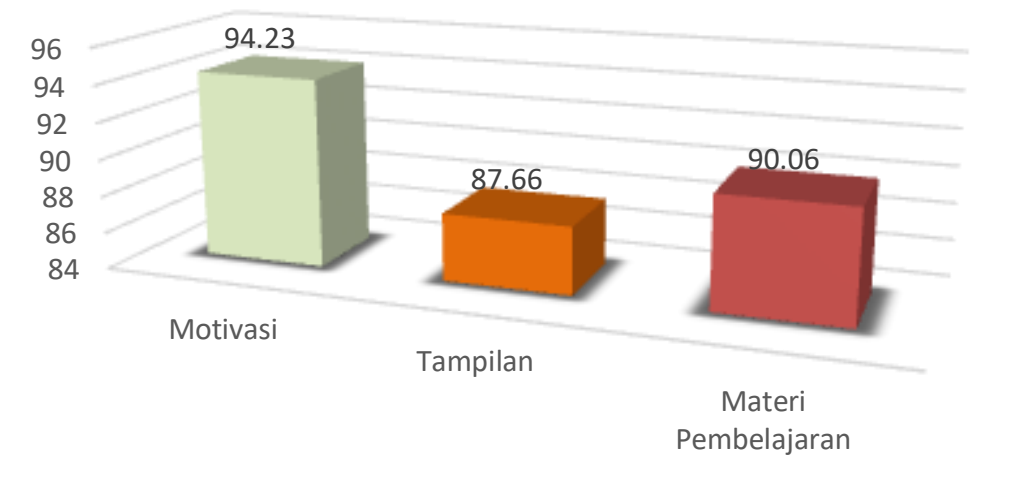

Gambar 4.2. Diagram Batang Uji Besar/Lebih Luas

Hasil validasi ahli media terhadap Aplikasi Media Pembelajaran Berbasis Web Dengan Menggunakan Microsoft Expression Web Pada Mata Pelajaran Ipa Terpadu Di SMP Negeri 2 Konawe Selatan dengan melibatkan 3 orang yang berlatar belakang pendidikan sarjana Komputer (S.Kom) diperoleh hasil sebagai berikut : Hasil validasi oleh ahli media ditinjau dari aspek Komunikasi yang terdiri dari 5 pertanyaan yaitu Kemudahan memulai program, Logika berpikir, interaksi dengan pengguna, kejelasan petunjuk penggunaan dan penggunaan bahasa, memperoleh nilai sebesar 45 atau 75,00 \%. Dari aspek desain teknis yang terdiri dari 4 pertanyaan yaitu format teks, penggunaan warna, kualitas gambar, dan penggunaan tombol interkatif memperoleh nilai sebesar 38 atau 79,17\%, dan dari aspek urutan penyajian terdiri dari 2 pertanyaan yaitu transisi antar halaman dan tampilan program memperoleh nilai sebesar 19 atau 79,17 \%. Secara keseluruhan Aplikasi Media Pembelajaran Berbasis Web Dengan Menggunakan Microsoft Expression Web Pada Mata Pelajaran Ipa Terpadu Di SMP Negeri 2 Konawe Selatan adalah sebesar 102 atau 77,27 \%. Sesuai dengan table 3.4 pada bab III diatas NIlai 77,27 \% sangat layak digunakan. Dengan Demikian tingkat validasi ahli media terhadap Aplikasi Media Pembelajaran Berbasis Web 
Dengan Menggunakan Microsoft Expression Web Pada Mata Pelajaran Ipa Terpadu Di SMP Negeri 2 Konawe Selatan dapat diinterprestasikan sangat layak digunakan.

Tabel 4.3. Hasil Validasi Ahli Media

\begin{tabular}{|l|l|l|l|l|l|}
\hline No. & Aspek Penilaian & $\begin{array}{l}\text { Skor } \\
\text { Observasi }\end{array}$ & $\begin{array}{l}\text { Skor Yang } \\
\text { diharapkan }\end{array}$ & $\begin{array}{l}\text { Kelayakan } \\
(\%)\end{array}$ & Ket. \\
\hline 1. & Komunikasi & 45 & 60 & 75,00 & Sangat Layak \\
\hline 2. & Desain Teknis & 38 & 48 & 79,17 & Sangat Layak \\
\hline 3. & Urutan Penyajian & 19 & 24 & 79,17 & Sangat Layak \\
\hline Jumlah & 102 & 132 & 77,27 & Sangat Layak \\
\hline
\end{tabular}

Sumber : Hasil Olahan, 2015

Bila digambarkan dalam bentuk diagram batang adalah sebagai berikut:

\section{Data Hasil Validasi Ahli Media}
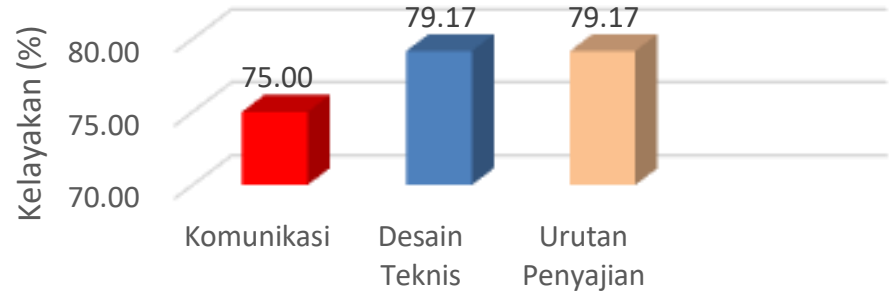

Aspek Penilaian

Gambar 4.3. Diagram Batang Validasi Ahli Media

Hasil validasi ahli materi terhadap Aplikasi Media Pembelajaran Berbasis Web Dengan Menggunakan Microsoft Expression Web Pada Mata Pelajaran Ipa Terpadu Di SMP Negeri 2 Konawe Selatan dengan melibatkan 2 orang guru Ipa Terpadu adalah sebagai berikut : Hasil validasi ahli materi dinilai dari aspek Isi dan Tujuan terdiri dari 4 pertayaan yaitu Ketepatan, keseimbangan, minat perhatian dan kesesuaian memperoleh nilai sebesar 28 atau 87,50\%, Aspek efisien terdiri dari 1 item pertanyaan yaitu Efisien program memperoleh nilai 7 atau 87,50 \% dan Aspek efektifitas terdiri dari 1 item pertanyaan yaitu efektifitas program memperoleh nilai 8 atau $100 \%$. Dari hasil validasi ahli materi terhadap Aplikasi Media Pembelajaran Berbasis Web Dengan Menggunakan Microsoft Expression Web Pada Mata Pelajaran Ipa Terpadu Di SMP Negeri 2 Konawe Selatan Sesuai dengan table 3.4 pada bab III diatas Nilai 89,58 \% sangat layak digunakan. Dengan Demikian tingkat validasi ahli media terhadap Aplikasi Media Pembelajaran Berbasis Web Dengan Menggunakan Microsoft Expression Web Pada Mata Pelajaran Ipa Terpadu Di SMP Negeri 2 Konawe Selatan dapat diinterprestasikan sangat layak digunakan.

Tabel 4.4. Hasil Validasi Ahli Materi

\begin{tabular}{|l|l|l|l|l|l|}
\hline No. & Aspek Penilaian & $\begin{array}{c}\text { Skor } \\
\text { Observasi }\end{array}$ & $\begin{array}{c}\text { Skor } \\
\text { Yang } \\
\text { diharapk } \\
\text { an }\end{array}$ & $\begin{array}{c}\text { Kelayakan } \\
(\%)\end{array}$ & \multicolumn{1}{|c|}{ Ket. } \\
\hline 1. & Isi dan Tujuan & 28 & 32 & 87,50 & Sangat Layak \\
\hline 2. & Efisien & 7 & 8 & 87,50 & Sangat Layak \\
\hline 3. & Efektifitas & 8 & 8 & 100 & Sangat Layak \\
\hline Jumlah & 43 & 48 & 89,58 & Sangat Layak \\
\hline
\end{tabular}


Sumber : Hasil Olahan, 2015

Bila digambarkan dalam bentuk diagram batang adalah sebagai berikut:

Gambar 4.4. Diagram Batang Validasi Ahli Materi

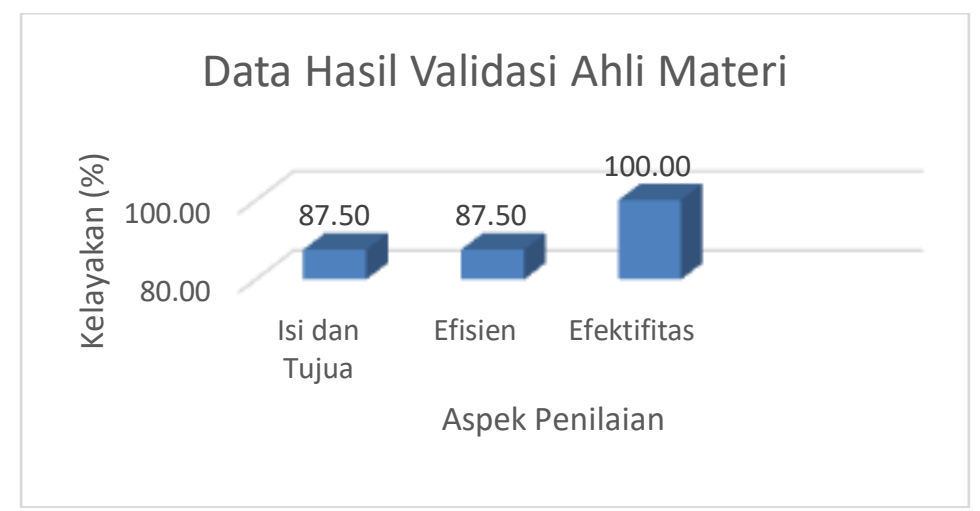

Dari hasil uji coba dan validasi kelayakan terhadap Aplikasi Media Pembelajaran Berbasis Web Dengan Menggunakan Microsoft Expression Web Pada Mata Pelajaran Ipa Terpadu Di SMP Negeri 2 Konawe Selatan dapat disimpulkan bahwa Aplikasi Media Pembelajaran Berbasis Web Dengan Menggunakan Microsoft Expression Web Pada Mata Pelajaran Ipa Terpadu Di SMP Negeri 2 Konawe Selatan yang didesain sangat layak digunakan dengan rata-rata persentase kelayakan sebesar $87,81 \%$. Dengan rata-rata 87,81 $\%$ telah sesuai dengan kriteria kelayakan yang dikemukakan oleh arikunto (1996) bahwa Kriteria dikatakan sangat layak apabila mencapai 76\% - 100\%. Dengan demikian Aplikasi Media Pembelajaran Berbasis Web Dengan Menggunakan Microsoft Expression Web Pada Mata Pelajaran Ipa Terpadu Di SMP Negeri 2 Konawe Selatan sangat layak digunakan sebagai media pembelajaran pada mata pelajaran Ipa Terpadu pokok bahasan listrik statis.

\section{KESIMPULAN DAN SARAN}

\section{Kesimpulan}

Berdasarkan hasil penelitian dan pembahasan maka dapat ditarik kesimpulan bahwa : Aplikasi Media Pembelajaran Berbasis Web Dengan Menggunakan Microsoft Expression Web Pada Mata Pelajaran Fisika Di SMP Negeri 2 Konawe Selatan sangat layak digunakan sebagai media pembelajaran pada mata pelajaran fisika pokok bahasan listrik statis. Hasil uji coba kelompok kecil atau terbatas terhadap Aplikasi Media Pembelajaran Berbasis Web Dengan Menggunakan Microsoft Expression Web Pada Mata Pelajaran Fisika Di SMP Negeri 2 Konawe Selatan adalah 87,92 \%, dapat diinterprestasikan sangat layak digunakan. Hasil uji coba kelompok besar atau lebih luas $t$ erhadap Aplikasi Media Pembelajaran Berbasis Web Dengan Menggunakan Microsoft Expression Web Pada Mata Pelajaran Fisika Di SMP Negeri 2 Konawe Selatan adalah 89,04\%, dapat diinterprestasikan sangat layak digunakan. Tingkat validasi ahli media terhadap Aplikasi Media Pembelajaran Berbasis Web Dengan Menggunakan Microsoft Expression Web Pada Mata Pelajaran Fisika Di SMP Negeri 2 Konawe Selatan adalah 77,27 \% dapat diinterprestasikan sangat layak digunakan. Tingkat validasi ahli media terhadap Aplikasi Media Pembelajaran Berbasis Web Dengan Menggunakan Microsoft Expression Web Pada Mata Pelajaran Fisika Di SMP Negeri 2 Konawe Selatan adalah 89,58\% dapat diinterprestasikan sangat layak digunakan. 
Aplikasi Media Pembelajaran Berbasis Web Dengan Menggunakan Microsoft Expression Web Pada Mata Pelajaran Fisika Di SMP Negeri 2 Konawe Selatan yang didesain sangat layak digunakan dengan rata-rata persentase kelayakan sebesar 87,81.

\section{Saran}

Bagi peneliti berikutnya yang akan mengembangkan Aplikasi Media Pembelajaran Berbasis Web Dengan Menggunakan Microsoft Expression Web Pada Mata Pelajaran Fisika Di SMP Negeri 2 Konawe Selatan disarankan :

1. Dalam pengembangan aplikasi media pembelajaran ini disarankan untuk merancang dalam 1 semester penuh.

2. Dalam hal evaluasi, perlu di tambahkan bank soal yang di tampilkan secara random.

3. Dalam penelitian selanjutnya agar melihat pengaruhnya terhadap hasil belajar siswa.

\section{DAFTAR PUSTAKA}

Arikunto, Suharsimi. 1996. Prosedur Penelitian Suatu Pendekatan Praktek, Jakarta, PT. Rineka Cipta.

Arsyad, Azhar. 2006. Media Pembelajaran, Jakarta. PT. Raja Grafindo Persada, 2010. Media Pembelajaran, Jakarta. PT. Raja Grafindo Persada, 2013. Media Pembelajaran, Jakarta. PT. Raja Grafindo Persada,

Darman, 2010. Skripsi Desain media pembelajaran berbasis komputer dengan menggunakan microsoft expression web pada mata kuliah pemrograman web di universitas muhammadiyah kendari.

Daryanto, 2010. Media Pembelajaran. Bandung, Satu Nusa.

Rusman, 2012. Belajar dan Pembelajaran Berbasis Komputer Mengembangkan Profesionalisme Guru Abad 21, Bandung. Alfabeta, 2013. Model-Model Pembelajaran Mengembangkan profesionalisme guru, Jakarta, Rajawali Pers.

Sadiman, Arief. S, 2006. Media pendidikan: Pengertian, pengembangan dan pemanfaatan. Jakarta, PT. Raja Grafindo Persada.

2003. Media Pendidikan (Pengertian Pengembangan dan Pemafaatannya). Jakarta, CV. Rajawali.

2011. Media pendidikan. Pengertian, Pengembangan dan Pemanfaatanya. Jakarta, Rajawali Pers.

Sanjaya, Wina 2008. Perencanaan dan Desain Sistem Pembelajaran, Jakarta, Kencana Prenada Media Group. 2012. Media Komunikasi Pembelajaran, Jakarta, Kencana Prenada Media Group.

Iskandar, 2010. Metodologi penelitian pendidikan dan sosial (Kuantitatif dan Kualitatis), Jakarta. Gaung Persada Press,

Sudjana,Nana, 2001. Media Pengajaran, Bandung, Sinar Baru Algesindo.

Sugiono, 2010. Metode Penelitian Kuantitatif, Kualitatif dan R\&D, Bandung, Alfabeta. 